Review

\title{
Microwave heating processing as alternative of pretreatment in second- generation biorefinery: An overview
}

\author{
Alejandra Aguilar-Reynosa ${ }^{a}$, Aloia Romaní ${ }^{b}$, Rosa Ma. Rodríguez-Jasso ${ }^{a, c}$, Cristóbal N. Aguilar ${ }^{a}$, \\ Gil Garrote ${ }^{\mathrm{d}, \mathrm{e}}$, Héctor A. Ruiz ${ }^{\mathrm{a}, \mathrm{c}, *}$ \\ a Biorefinery Group, Food Research Department, School of Chemistry, Autonomous University of Coahuila, 25280 Saltillo, Coahuila, Mexico \\ ${ }^{\mathrm{b}}$ CEB-Centre of Biological Engineering, University of Minho, Campus Gualtar, 4710-057 Braga, Portugal \\ ${ }^{c}$ Cluster of Bioalcoholes, Mexican Centre for Innovation in Bioenergy (Cemie-Bio), Mexico \\ ${ }^{\mathrm{d}}$ Department of Chemical Engineering, Faculty of Science, University of Vigo (Campus Ourense), As Lagoas, 32004 Ourense, Spain \\ ${ }^{\text {e } C I T I ~(C e n t r o ~ d e ~ I n v e s t i g a c i o ́ n, ~ T r a n s f e r e n c i a ~ e ~ I n n o v a c i o ́ n), ~ U n i v e r s i t y ~ o f ~ V i g o, ~ T e c n o p o l e, ~ S a n ~ C i p r i a ́ n ~ d a s ~ V i n ̃ a s, ~} 32901$ Ourense, Spain
}

\section{A R T I C L E I N F O}

\section{Article history:}

Received 7 October 2016

Received in revised form 27 December 2016

Accepted 3 January 2017

\section{Keywords:}

Biorefinery

Pretreatment

Lignocellulosic material

Microwave heating

Bioethanol

Biofuels

\begin{abstract}
A B S T R A C T
The development of a feasible biorefinery is in need of alternative technologies to improve lignocellulosic biomass conversion by the suitable use of energy. Microwave heating processing (MHP) is emerging as promising unconventional pretreatment of lignocellulosic materials (LCMs). MHP applied as pretreatment induces LCMs breakdown through the molecular collision caused by the dielectric polarization. Polar particles movement generates a quick heating consequently the temperatures and times of process are lower. In this way, MHP has positioned as green technology in comparison with other types of heating. Microwave technology represents an excellent option to obtain susceptible substrates to enzymatic saccharification and subsequently in the production of bioethanol and high-added compounds. However, it is still necessary to study the dielectric properties of materials, and conduct economic studies to achieve development in pilot and industrial scale. This work aims to provide an overview of recent progress and alternative configurations for combining the application of microwave technology on the pretreatment of LCMs in terms of biorefinery.
\end{abstract}

(c) 2017 Elsevier Ltd. All rights reserved.

\section{Contents}

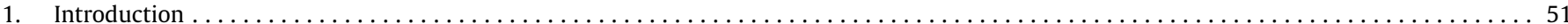

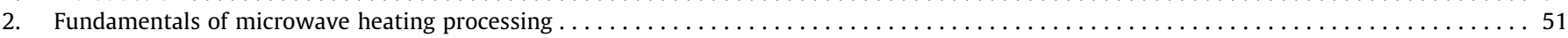

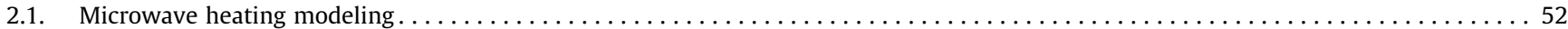

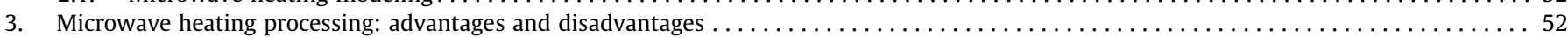

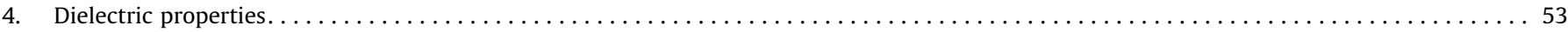

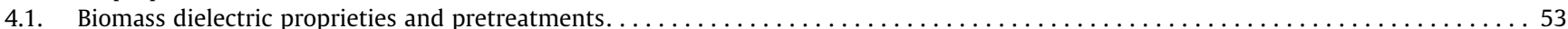

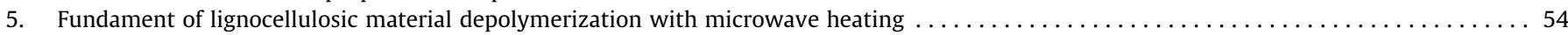

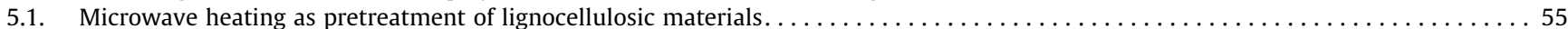

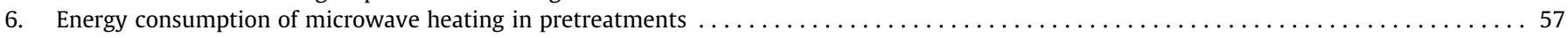

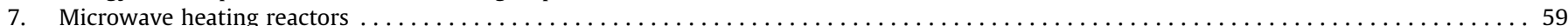

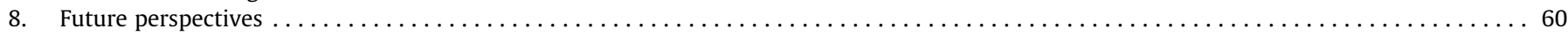

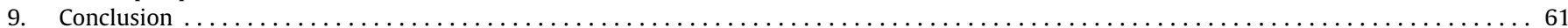

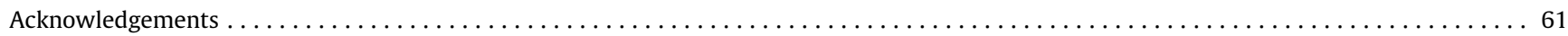

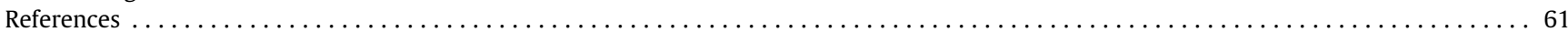

Abbreviations: LCMs, lignocellulosic materials; MHP, microwave heating processing; MHz, megahertz; GHz, gigahertz; $\varepsilon^{\prime}$, dielectric constant; $\varepsilon^{\prime \prime}$, dielectric loss; tan d, loss

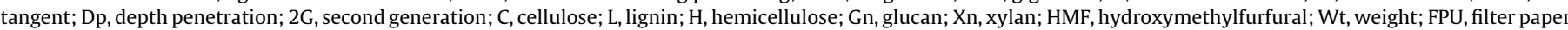

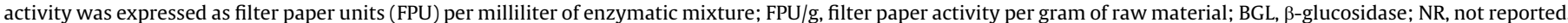
* Corresponding author at: Biorefinery Group, Food Research Department, School of Chemistry, Autonomous University of Coahuila, 25280 Saltillo, Coahuila, Mexico.

E-mail addresses: rrodriguezjasso@uadec.edu.mx (R. Ma. Rodríguez-Jasso), hector_ruiz_leza@uadec.edu.mx (H.A. Ruiz). 


\section{Introduction}

The biofuels obtained from LCMs also known as secondgeneration biofuels $(2 \mathrm{G})$ have been proposed as an alternative to reduce the dependence on fossil fuels [1,2]. Furthermore, $2 \mathrm{G}$ biofuels are obtained from renewable sources that are available in enough amount for a large scale production, their price is low and they have geographical diversity of supply [3]. The main steps involved in $2 \mathrm{G}$ bioethanol or lignocellulosic ethanol production are: (1) particle size reduction of LCMs, (2) pretreatment of LCM, (3) enzymatic hydrolysis of cellulose, (4) fermentation and (5) rectification-distillation (composed by a separation and ethanol purification) [4,5].

In this sense, LCMs pretreatment plays an important role to achieve a feasible bioethanol conversion, since it is necessary to break down the LCMs complex structure [6]. Pretreatment enables the modification of crystalline structures of cellulose, solubilization and depolymerization of hemicellulose and in some cases the lignin can be removed depending on the type of pretreatment used [7]. This important step allows an easier access for enzyme towards cellulose to obtain fermentable sugars [8].

On other hand, pretreatment is considered one of the most expensive stages in $2 \mathrm{G}$ bioethanol production taking up to 20 $48 \%$ of the total operational cost [9], besides is the step where more energy is consumed $[10,11]$. In this context, many researchers are focused on the development of suitable pretreatments. The main challenge in the development of pretreatments is the following: (1) low operational cost, (2) application in a wide range of LCMs (3) easy recovery of the products in the liquid and solid phase, (4), low energy consumption, (5) robust for continuous operation and high loading material [12-15].

In general terms, the authors have classified the pretreatments as: (1) physical: milling, extrusion, freeze and microwave heating; (2) chemical: alkaline acid, dilute acid, ionic liquids, organosolv and ozonolysis; (3) physicochemical: steam explosion, fiber explosion ammonium, $\mathrm{CO}_{2}$ explosion, liquid hot water, wet oxidation and (4) biological pretreatment: fungus $[14,16]$. It is important to mention that the combination of these pretreatments is necessary in some cases, depending on the compound to produce and in terms of a biorefinery.

Recently, microwave processing has attracted attention since it satisfies many requirements of green chemistry [17]. MHP avoids the use of solvents, separation agents, or other auxiliary chemicals and smokes and wastes are not generated. Moreover, time of process is reduced by 10 times less in comparison with other heating systems, which decreases the energy consumption [18]. The MHP has fast heat transfer [11], consequently, this technology allows redefining a lot of reactions where the thermal factor plays an essential role in the process. Also, this technology is considered as an alternative method to conventional heating and has been widely used in several areas due to its efficacy and it is easy to operate [19].

This review deals the fundamentals of microwave heating processing and provides an overview of its application as pretreatment (main reactions and its effect on lignocellulosic fractionation).

\section{Fundamentals of microwave heating processing}

In 1949 the engineer Percy L. Spencer discovered that electromagnetic frequency radiation could heat dielectric materials. After, some companies (such as General Electric and Raytheon) patented various systems focused on industrial heating and domestic appliances. Likewise Spencer's patent was the first to propose the use of microwaves for heating and food applications [20]. Later in 1954,
Von Hippel proposed a theory to understand the macroscopic interactions of microwave with the matter [21]. Interactions between electromagnetic waves and matters are expressed as conductive losses, dielectric losses, magnetic losses, etc. These mechanisms originate dielectric heating (microwave heating) that it is dependent on the electromagnetic field characteristics and the properties of the material [22]. His theory explained dissipated power, electric field intensity and propagation constant concepts.

Microwaves are a kind of electromagnetic radiation that is shaped like energy propagating in a vacuum in the absence of any material in motion. Microwaves can be observed as light and can be used as waves. They are non-ionizing waves, similar to low frequency waves used in cell phones and infrared [23]. Furthermore, microwaves are originated by the reversing of the dipole (separation of two charges positive and negative of equal magnitude which are separated by a fixed distance). Consequently, the positive charge goes to the bottom and the negative charge at the opposite side [21]. This fact also causes the reverse field, generating the inversion of the force that acting on it. This phenomenon does not occur immediately when the dipole is changed there is a very short time to propagate the change at this point. The continued investment of the dipole is called oscillation $[21,24]$. The oscillation generates the electric field, but also exist oscillation for the propagation and the formation of a magnetic field, these two oscillating fields produce an electromagnetic radiation, which are measured as frequencies. These frequencies are the number of complete oscillations of a particle performed in a unit of time, usually in one second $\left(\mathrm{s}^{-1}\right.$ or Hertz). The space between the oscillations is called wavelength [23]. Microwaves have a frequency in a range from $300 \mathrm{MHz}$ to $300 \mathrm{GHz}$ and a wavelength from $1 \mathrm{~m}$ to $1 \mathrm{~mm}[25,26]$. In this way, the alignment of polar molecules caused by microwave irradiation forces the molecule dipoles to align in the radiation field (polarized). The realignment of polar molecules produces a displacement inside of the material which generates heat [21,27].

In this way, the alignment of polar molecules caused by microwave irradiation forces the molecule dipoles to align in the radiation field (polarized). The realignment of polar molecules produces a displacement inside of the material which generates heat $[21,28]$.

MHP is generated through the friction from the rotational forces of the polar molecules present, these molecules attempt to direct by themselves in the direction of the oscillating microwave field as it is shown in Fig. 1 [29]. The band from 2.4 to $2.4853 \mathrm{GHz}$ is usually used to produce microwaves [20]. This level of frequencies allows a homogeneous and efficient heating. Nevertheless, in some industrial applications, frequencies of $9.15 \mathrm{GHz}$ are used. These frequencies show more uniform heating in bulk, besides provides an efficiency of energy transformation of about $85 \%$ whereas with $2.4 \mathrm{GHz}$ only $80 \%$ [30].

MHP is produced directly from inside the material, leading to better heat transfer, and substantially it has a higher energy yield comparing to conventional ovens which transmit heat by conduction-convection [31]. Microwaves have low energy in their photons $(0.03 \mathrm{kcal} / \mathrm{mol})$. Therefore, microwaves do not affect directly the molecular structures, since the chemical bonds have an energy ranging from 20 to $50 \mathrm{kcal} / \mathrm{mol}$. For this reason, it is considered a non-ionizing radiation. The arousal effect of the molecules by microwaves application only increases kinetic energy [32].

Heat propagation is carried up into two mechanisms (Fig. 1): (1) Ionic conduction is carried out where there are free ions or ionic species and the molecules are oriented by themselves by ionic motion generated in the electric field, thereby causing quick heating, if the solution is denser, there are more shocks and therefore more kinetic energy is converted. (2) Bipolar rotation referring to an interaction where polar molecules try to align themselves as fast as does the electric field. The movement causes friction 


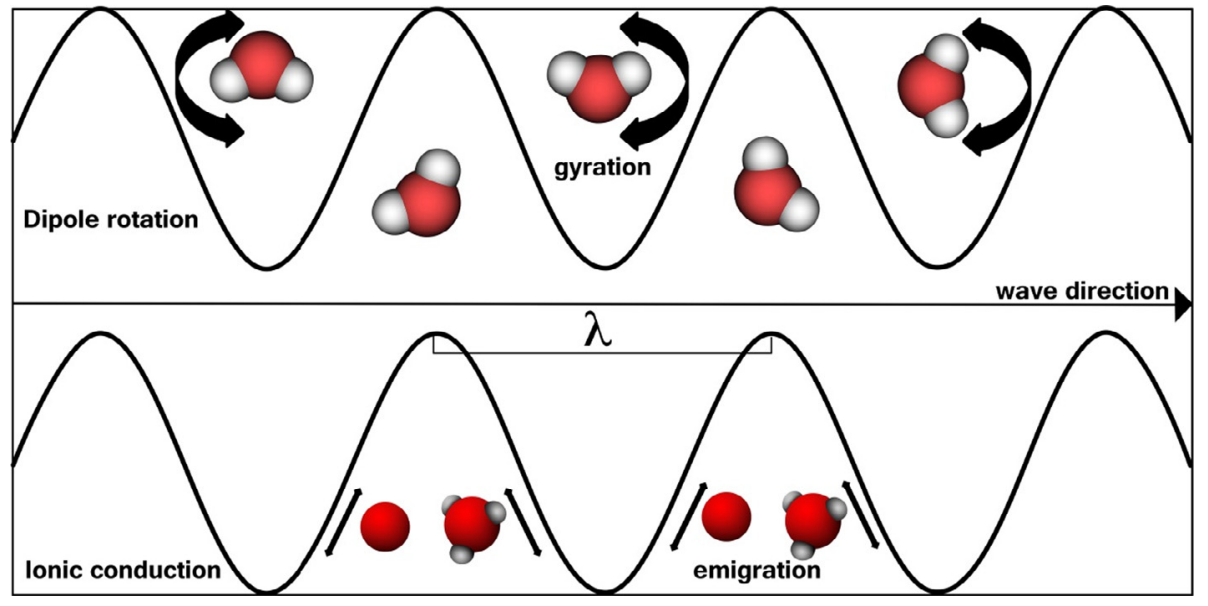

Fig. 1. Propagation mechanisms of MHP.

between molecules and then it transfers energy that becomes heat as the result of the molecules rotation. When the field is removed, the molecules return to their disordered orientation and the time to realign depends on the size of the molecule. As temperature increases, the molecules tend to align to their original orientation quickly. The ability to perform the bipolar rotation is related with the polarity of the molecules and the dielectric properties [33-35].

On the other hand, the dielectric properties have great importance in MHP, due to dielectric materials can be polarized by an electrical field and they have good electromagnetic interaction [36]. Dielectric property or permittivity is the ability of a dielectric material to store electrostatic energy in presence of an electric field. Dielectric heating is related with the dissipated power converted into heat inside the material, for this reason MHP is known as dielectric heating. Moreover, water is one of the main molecules that interacts with the microwaves because it has high dielectric factor $[20,36]$. Water presence inside the materials facilitates the heating, because water flow raises the temperature in the entire volume approximately at the same rate. The moisture determines the dielectric properties of the materials and ions content because both control the depth of penetration of the waves in the material. [37]. Dielectric materials have relaxation frequencies, equivalent to the time where the energy is absorbed and emitted by effect of the electric field. At relaxation frequencies, atoms and molecules present in the material absorb effectively the radiation [38]. This relaxation phenomenon is originated for the reorientation of the permanent dielectric dipoles when are subjected to an oscillating field. Dipoles require a time to revert to a random distribution in equilibrium with the temperature of the medium from an oriented alignment. Dielectric relaxation is studied to reduce energy losses in materials [39].

\subsection{Microwave heating modeling}

The development of mathematical models of MHP as a tool to study the influence of various parameters on the raw material, starts with the necessity to find solutions to the problems and understand the behaviors of this type of heating, mainly the nonuniform heating $[25,33]$. Such models are based on predicting patterns of temperature and electromagnetic energy distribution in the heated material [40]. Maxwell's equations are applied in MHP modeling the heat source description. Maxwell equations lead to determination of the spatial distribution of electromagnetic field, when heat transfer rate is faster the modeling is based on Maxwell's equations, as well as the Lambert's law assumes an exponential decay of the microwave power in the heated material.
These models give only an approximate to the exact solution obtained with Maxwell's equations. Although, the computation based on the Lambert's law gives good results in case of thick wide or when the sample depth is smaller than the penetration depth [40-43].

Most of mathematical models are based on description of solids heating. Moreover, the microwaves are used to heat water flow systems and there is little research about liquid layer. Liquids heating with microwaves have uneven heating distribution in the water flowing due to non-uniform electric field patterns. Uniformity in liquid layer heating can be solved by utilizing a focused system and taking in account factors which influence the heating patterns like dielectric properties, ionic concentration, volume, and product shape $[37,44]$.

The MHP mathematical models of liquids are more demanding than the models for solids, due to the combination of three phenomena: the electromagnetism, heat transfer and fluid dynamics, compared with models of solid that only consider the first two [43]. Pretreatments generally are carried out in a mix of LCMs and aqueous phase that can be water, acids, alkali or ionic liquids. The mixture forms an emulsion, which finally is submitted to pretreatment, but in this sense, there is little information on mathematical models for mixtures of solids with liquids.

\section{Microwave heating processing: advantages and disadvantages}

MHP offers many advantages over conduction and convection heating, for example: (1) faster heat transfer and shorter reaction times [45]; (2) the heating is dielectric, volumetric (around all material) and selective due to the heating is specific on molecules with dipole [46]; (3) the MHP offers an energy-efficient route of heating and therefore cost-effective [47]; (4) the heating is carried out directly within the mixture, there is not direct contact with the heat source, in this way surfaces overheating is prevented [48]; 4) MHP allows to obtain high products yields [49], (5) the equipment has good compactness, this characteristic allows equipment place repositioning, besides the turn on and turn off is instantaneous [48], (6) the non-conductor vessel used for heating avoids heat loss, because the microwaves pass through the vessel wall without heating it [50], (7) MHP can be considered friendly environment process [51]; (9) low degradation or formation of side products due to the short reaction times [52], (10) MHP allows the material overheating, because the maximum temperature achieved is not limited by the boiling point [32], (11) MHP improves moisture 
reduction, this point can be considered as an advantage or disadvantage depending on the type of process [33].

On the other hand, MHP has some disadvantages. The main drawback is the distribution of microwave power around of material due to non-homogeneous material (composition, geometry, and ranges of size). MHP is non-uniform, the electromagnetic waves reflection resulting in formation of the standing waves. This phenomenon is called as resonance and it leads to local overheating, also known as heat spot [22,53]. However, the hot spots in materials may be controlled with the distributed microwave incidence in a closed system, besides controlling the proper thickness [53]. Other disadvantages in MHP are the low penetration of radiation in bulk products. Some materials have low energy absorption due to the dielectric properties possessed and in some materials mainly in foods, the dielectric properties strongly change with the temperature, (i.e. defrost) and therefore also its microwave absorption [54].

\section{Dielectric properties}

Dielectric constant $\left(\varepsilon^{\prime}\right)$ is the ability of molecules to be polarized by an electric field and thereby to store electric energy; this part is called the real part of the dielectric properties. Dielectric constant can be affected by the molecular weight, molecule shape and direction of their links [55].

Dielectric loss $\left(\varepsilon^{\prime \prime}\right)$ is the amount of energy lost in the material to be dissipated into heat when it contacts the microwaves. Dielectric loss can be determined as the ability to convert electrical energy into heat and it is caused by free electron conductivity. It is considered the imaginary part of the dielectric properties, and as lower as its value, the material has less ability to absorb microwaves [56,57]. Dielectric losses decrease when temperature increases, therefore, they are partially self-controllable [58].

The relation between the two parameters is known like dielectric loss tangent or dissipation factor $\left(\tan d=\varepsilon^{\prime} / \varepsilon^{\prime \prime}\right)$. This parameter is used to describe the material capacity to be heated by microwaves. It is a dimensionless parameter that reflects the energy losses in a dielectric material, in the case that $\varepsilon$ ' is zero the loss tangent is also overridden [35].

Additionally, the materials can be classified according to the dielectric loss tangent present as conductive materials, nonconductors and dielectric materials. (i) Dielectric materials cannot penetrate by microwaves, they have $\tan d<0$, for example the metal; (ii) Non-conductor materials are transparent to microwaves and have low or null dielectric loss, they have a level of tan $\mathrm{d}$ from 0.1 to 0.5 , some examples are teflon, glass, quartz and air. Non-conductors materials are the main materials used to manufacture vessels or reactors to heat with MHP; (iii) Dielectric materials: these absorb microwaves, having high levels of tan $\mathrm{d}>0.5$, they are ideal materials to heat by MHP, for example water $[21,59]$.

In this sense, in the most of pretreatments, water is the main solvent for LCMs mixtures, therefore, the presence of $\mathrm{H}+$ ion improves the dielectric loss factor due to ionic conduction mechanism and water is the main responsible for the electrical polarization [60]. Salts and carbohydrates dissolved in water reduce the relative permittivity. In a mixture with lower salt content, the dielectric properties are mainly conducted by water at higher frequencies and sugars have a weak effect on polarization or dielectric loss [61]. The permittivity drop of mixtures with water is the result of two mechanisms: (1) binding of free water molecules and (2) water volume replacement with a substance that contains a lower permittivity [62]. According to these facts, LCMs mixtures are good microwaves drivers due to its polarity compounds (cellulose, hemicellulose and lignin) and water presence.
Other important parameter is the penetration depth (Dp); this parameter is affected by the modification of the dielectric properties and layer thickness. Dp defines the depth that can dissipate microwaves inside of the material [63]. Dielectric constant and dielectric loss are related because both determine the amount of energy absorbed in the material and the Dp [64]. Besides of dielectric properties, there are other parameters that influence the absorption and transfer of microwaves to achieve uniform heating as: chemical composition, thermal diffusivity, thermal conductivity, specific heat, particle size and density [59,65].

\subsection{Biomass dielectric proprieties and pretreatments}

Currently many researchers have used the microwave as heating source during pretreatment in $2 \mathrm{G}$ biofuels production but in most of the works where MHP has been used the dielectric properties of the LCMs were not studied. However, it is necessary to know the dielectric properties to understand the material interactions with the electromagnetic energy, as well as the estimation of the penetration depth. Dielectric properties help to determine the optimal conditions to heat LCMs by MHP. In this sense, when a material is more dipolar, the process present more dielectric losses and therefore more heat is generated inside. A high loss factor indicates that the material is susceptible to being treated with microwaves while a factor of low loss indicates otherwise. In Table 1 are shown some dielectric properties for some types of LCMs that have been studied. As it mentioned previously, the material composition is an important characteristic in the MHP. LCMs content hydroxyl groups strongly polarized with high hydrophilic properties and the presence of non-polar lignocellulosic fibers and polar groups lead in the dipole formation. Therefore the dielectric constant increases with a high load of fibers at all frequencies [66].

On the other hand, inside of LCMs the electric current flows in a higher amount by the crystalline region (cellulose), whereas in the amorphous region the current flow flows due to the presence of moisture $[73,74]$. In literature it is possible to find the development of pretreatments using some catalysts in combination with MHP. However, it is necessary consider that the addition of acids or alkalis in the pretreatments could decrease the orientation of the polarization in the material during the heating. A stronger pretreatment can reduce the hydrophobicity of the fibers, generating unlocked hydrogen bonds making them more reactive. This fact decrease the orientation of the polarization and dielectric constant [73]. Also, the electrolytic presence increases the dielectric loss in a frequency less than $2.45 \mathrm{GHz}$ [75]. Significant changes were observed when was applied MHP with acid, whereby many sizes of pores and channels were formed after perform a combined pretreatment in water hyacinth biomass [76]. $\mathrm{NaOH}$, metal complexes and halide ions have sensitizer effects that decrease the temperature, reaction time and energy requirement in biomass pretreatment with MHP [77,78]. Verma et al. [79] used MHP with ammonium ions pretreatments, they showed that ammonium molybdate is transformed to peroxometal complex when reacting with $\mathrm{H}_{2} \mathrm{O}_{2}$ this complex acts as a microwave sensitizer that absorbs microwave energy to accelerate the catalysis.

Verma et al. [79] used MHP with ammonium ions pretreatments, they showed that ammonium molybdate is transformed to peroxometal complex on reacting with $\mathrm{H}_{2} \mathrm{O}_{2}$ this complex acts as a microwave sensitizer that absorbs microwave energy to accelerate the catalysis.

MHP in combination with water takes place in autohydrolysis pretreatment [19]. In autohydrolysis pretreatment with MHP, the presence of hemicellulose fraction improves the current flow, due to its ability to absorb moisture, resulting in a higher dissipation associated with the amorphous phase relaxations [73]. When autohydrolysis is performed, a controlled hydrolytic solubilization and 
Table 1

Biomass dielectric proprieties.

\begin{tabular}{|c|c|c|c|c|c|c|}
\hline Materials & Frequency & Dielectric constant & Loss factor & Tangent loss & Penetration depth (cm) & Reference \\
\hline Oil palm fiber & $2.45 \mathrm{GHz}$ at $500{ }^{\circ} \mathrm{C}$ & 1.99 & 0.16 & 0.08 & 24.8 & [67] \\
\hline Oil palm Shell & $2.45 \mathrm{GHz}$ at $500{ }^{\circ} \mathrm{C}$ & 2.76 & 0.35 & 0.12 & 13,4 & \\
\hline Oil palm Shell char & $2.45 \mathrm{GHz}$ at $500{ }^{\circ} \mathrm{C}$ & 2.83 & 0.23 & 0.08 & 20.6 & \\
\hline Empty fruit bunch (18 wt\% moisture) & $2.45 \mathrm{GHz}$ at $27^{\circ} \mathrm{C}$ & 6.4 & 1.9 & 0.3 & 3.5 & {$[68]$} \\
\hline EFB sample (64 wt\% moisture) & $2.45 \mathrm{GHz}$ at $27^{\circ} \mathrm{C}$ & 57.4 & 18.6 & & 0.9 & \\
\hline Wood & & 2.3 & & 0.11 & & [69] \\
\hline Fir plywood & & $\approx 1.5$ & & $0.01-0.05$ & & \\
\hline Particle board & & $\approx 2.5$ & & $0.1-1.0$ & & \\
\hline Bark (aspen) & & $\approx 9.4$ & & 0.22 & & \\
\hline Bark (pine) & & $\approx 4.4$ & & 0.18 & & \\
\hline \multirow[t]{2}{*}{ Switchgrass } & $9.15 \mathrm{GHz}$ at $150^{\circ} \mathrm{C}$ & 2.2 & 0.09 & 0.039 & $30 \mathrm{~m}$ & [57] \\
\hline & $2.45 \mathrm{GHz}$ at $150^{\circ} \mathrm{C}$ & 2.2 & 0.09 & 0.041 & $10 \mathrm{~m}$ & \\
\hline \multirow[t]{3}{*}{ Switchgrass char } & $9.15 \mathrm{GHz}$ at $689^{\circ} \mathrm{C}$ & 20 & 65 & 3.2 & $0.5 \mathrm{~cm}$ & \\
\hline & $2.45 \mathrm{GHz}$ at $689^{\circ} \mathrm{C}$ & 8 & 28 & 3.1 & $0.3 \mathrm{~cm}$ & \\
\hline & $10 \mathrm{kHz}$ at $180^{\circ} \mathrm{C}$ & 0.09 & 0.1 & & & \\
\hline Ayous Wood & $8.2 \mathrm{GHz}$ to $12.4 \mathrm{GHz}$ & 2.080 & 0.1849 & 0.09540 & & {$[70]$} \\
\hline Bubinga Wood & & 2.78 & -0.0211 & 0.06807 & & \\
\hline Mbey wood & & 1.685 & 0.1055 & 0.07229 & & \\
\hline Dibetou wood & & 1.845 & -0.125 & 0.059 & & \\
\hline Banana Fiber with polyurethane at $10 \%$ & $1 \mathrm{kHz}$ & 137 & 26 & & & [71] \\
\hline Pine wood & $2.45 \mathrm{GHz}$ & 2.7 & 0.53 & & 59 & [45] \\
\hline Pine wood & $2.4525^{\circ} \mathrm{C}$ at $\mathrm{GHz}$ & 13.4 & 0.08 & 0.006 & 0.2 & [72] \\
\hline Arabica coffee & & 26.8 & 3.14 & 0.117 & 0.5 & \\
\hline
\end{tabular}

depolymerization of hemicelluloses occurs. Reaction is catalyzed by the hydronium ions from water autoionization. Subsequently, hydronium ions coming from organic acids (acetic acid) generated in situ from hemicellulosic fraction, they are formed when the temperature increase [4,80-82]. High temperatures trigger the ions increase, allowing the solubilization of less polar substances as the hemicellulose [24]. Moreover, aqueous environments help to increase the penetration depth and uniform heating [83].

\section{Fundament of lignocellulosic material depolymerization with microwave heating}

In the cellulose crystalline region, the electron transport is possible by the neat hydrogen chain [84]. Moreover in the cellulose amorphous region, the electrical conductivity increases above the glass transition temperature besides between 150 and $180^{\circ} \mathrm{C}$ the ionic current arises and polarization is possible. Thus LCMs can be presented as alternative conductor with ionic regions (crystalline) and non-ionic regions (amorphous) [74]. Also, cellulose molecular chains have polar structure which are oriented when are subjected to an electric field [77]. In LCMs-solvent system, the polar molecules are the most important. When the microwave energy vibrates, these molecules are strongly heating resulting in hot spots formation [85]. High heat and vibrational motion could result in the rupture or explosion from some LCMs components, causing the crystalline cellulose relocation (Fig. 2).

Heat transfer by conduction-convection occurs when LCMs is placed on heated plates where heat is generated through the coil being transferred into the material. In contrast, microwave radiation causes LCMs breakdown, via molecular collision due to dielectric polarization [86]. Firstly, increase the temperature selectively in the more polar parts, causing non-homogeneous heating. Therefore, some hot spots are created within the material, and their explosion is generated due to the heat increase. The blast effect created between the particles by microwave heating improves the crystalline structures relocation [87]. Hot spots formation starts when the temperature uniformity is lost and their location depends on the heating period and water evaporation. This fact modifies the maximum energy point and then hot spots can relocate in the regions where there is still some moisture content [88].

A second theory to explain the changes in the material structure is due to the fast generation of pressure within of components during MHP, resulting in their fast expansion [29]. The $\mathrm{O}-\mathrm{H}$ bonds of

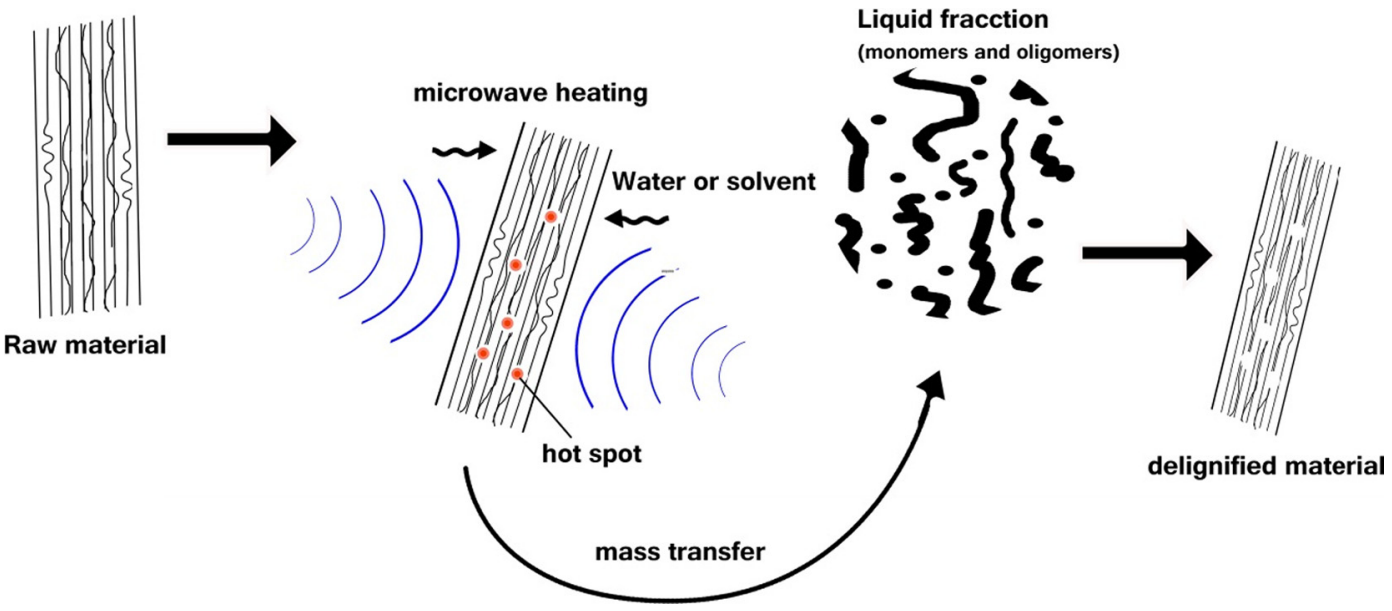

Fig. 2. Mechanism of MHP effects in lignocellulose pretreatment. 
the biopolymers absorb the microwaves efficiently, which might lead the heating acceleration and pressure increase [89]. However, components with not enough hydration or less polar fails to keep pace with granule expansion, and the resultant stress causes the structures collapse and in some cases their rupture [29]. Therefore, the temperature distribution and the heat transfer in all LCMs fractions play an important role to carry out this reaction with uniform heat and enough pressure. In this way, to apply a pretreatment, it is necessary to control the reaction in order to know the precise microwave irradiation influence. Water loss by evaporation, and microwave power level should be controlled. These facts provide a constant pressure and temperature control during the reaction to ensure accurate data on their effect [85].

\subsection{Microwave heating as pretreatment of lignocellulosic materials}

The earliest works that applied MHP to improve the enzymatic susceptibility of LCMs were reported by Ooshima et al. [90] and Azuma et al. [91]. In the last work, hardwoods (eucalypt, poplar and shirakanba) were pretreated by microwave-assisted autohydrolysis. The pretreated solids showed enzymatic susceptibility yields of $88-93 \%$ and the furfural production was low at high temperatures.

More recently, Gabhane et al. [92] studied acid pretreatment on banana wastes by 3 different power sources (autoclaving, MHP and ultrasonication) and their effect on reducing sugars production after enzymatic hydrolysis. The highest sugar yield (36.84\%) was obtained using acid-microwave pretreatment. Likewise, alkali pretreatment heated with microwaves has been the most studied combination. Zhu et al. [93] used acid and alkali pretreatment with MHP during $7 \mathrm{~min}$ and was observed that both pretreatments degrade hemicellulose and remove lignin in comparison with conventional pretreatment. Besides, MHP improved the lignin and hemicellulose solubilization and depolymerization, consequently decreases the crystallization degree of cellulose. Akhtar et al. [94] used microwave-alkali-acid pretreated during $3 \mathrm{~min}$ at $850 \mathrm{~W}$ and $150{ }^{\circ} \mathrm{C}$ on rice straw, they reported a cellulose increase up to $60.07 \%$, reduction of $14.90 \%$ of hemicelluloses and $4.52 \%$ of lignin and reduction of crystallinity index $(8.97 \%$ in comparison with native biomass). Singh et al. [95] also reported the increase of crystallinity index (54.55\%) of cellulose on rice straw pretreated by $\mathrm{NaOH}$ assisted with MHP. The presence of aqueous $\mathrm{NaOH}$ increased intermolecular saponification of ester bonds cross-linking lignin and hemicellulose improving the enzymatic saccharification. Lai et al. [96] observed an increment of $41.55 \%$ of cellulose content and a decrease of $6.99 \%$ of crystalline structure using microwavealkali pretreated oil palm trunks at 1:20 solid/liquid ratio. Table 2 summarizes the MHP in combination with other pretreatments to enhance the fractionation of LCM depolymerization.

In alkali pretreatments the microwaves can penetrate the material and directly vibrate the molecules. The molecules oscillation causes a fast heating and an eventually rupture of encrusted lignocellulosic structure. The oscillations disrupt both molecular hydrogen bonds which were incorporated within the structure. Similar behavior was reported by Hamzah et al. [114] using oil palm empty fruit bunch pretreated with microwave-alkali method and Wang et al. [115] using Apocynum venetum fibers.

On the other hand, in Table 3 are shown some works where MHP was combined with different pretreatments to improve enzymatic saccharification for subsequent fermentation for bioethanol production.

The pretreatment process plays an important role in the biorefinery concept, this stage allows the fractionation of the main components of the lignocellulosic material. Additionally, the biorefinery concept could use the combination of technologies and integration of biomass conversion processes to produce a range of biofuels, chemicals, and materials (high added-value compounds). Conceptually, a biorefinery would apply hybrid technologies from different fields including chemistry agriculture and bioengineering. This way the implementation of microwave technology as heating source during biomass pretreatment allows the development of systems that attempt to render the term "waste" in add-value products. Also, a biorefinery approach involves multi-step processes within pretreatment, for this reason microwave heating processing is positioned as an attractive technology due to the reduction of the number of chemical processes during pretreatment. Moreover, the problems related process as mass and heat transfer in the pretreatment process can be eliminated by the synergism between several technologies as MHP and ultrasound, while the reaction efficiency and overall process economics is improved significantly [124].

Bussemaker et al. [125] studied the combination of MHP and ultrasound process with oxidative media on wheat straw. The combination of ultrasonic with MHP increased the delignification up to $3.6 \%$ more than using only MHP, the effect was attributed to lignin condensation and the reduction of additional hemicellulose and inorganic material resulting in an increase of residues purity. Mai et al. [126] and Darji et al. [127] tested MHP in combination with ionic liquid, the highly ionic and polar nature of the medium causes an effective dissolution of LCM compounds. The collision frequency between anions and cations of ionic liquid and biomass macromolecules intensified the breakage of hydrogen bonds within structural chain. Karunanithy et al. [52] studied the sequential pretreatment method of extrusion-microwave using switchgrass and big bluestem as raw material. Operations were combined sequentially, first the material was milled and wetted, and then it was placed in an extruder process, where through a moving conveyor the MHP was applied. Extrusion-microwave pretreatment was carried up at $450 \mathrm{~W}$ for $2.5 \mathrm{~min}$ and $25 \%$ moisture, as a result the process did not show formation of HMF (hydroxymethylfurfural), furfural and formic acid, only acid acetic in low concentrations $0.12 \mathrm{~g} / \mathrm{L}$ using switchgrass and $0.11 \mathrm{~g} / \mathrm{L}$ with big bluestem were detected.

On the other hand, MHP was tested to improve the enzymatic saccharification process. Nomanbhay et al. [128] applied microwave irradiation to observe the influence of microwave and its non-thermic effects on the saccharification yield of oil palm empty fruit bunch fiber. Pretreatment was carried out at $100 \mathrm{~W}$ during $4 \mathrm{~h}$ with 1 break minute after every $10 \mathrm{~min}$. The results showed an increase of 5.8 fold in the saccharification yield and the use of $15 \mathrm{FPU} / \mathrm{g}$ of enzyme less. This behavior can be explained by the modification of active site on the enzyme due to molecular rotation and acceleration. Therefore there is more opportunity for the substrate to adjust to the enzyme per unit time [129]. MHP would be more efficient at short times, since more significant changes are registered for the variable of temperature $[130,131]$. It should be noted that heating is not the only factor causing effects on the structure, because the electromagnetic field applied creates nonthermal effects that accelerate the destruction of the crystalline structures, disruption of silicified waxy surface and breakdown of the lignin-hemicellulose matrix to release sugars [94]. However, it has been difficult to distinguish the role of thermal and nonthermal factors. Also, it should be consider factors that can affect enzymatic reactions, such as enzyme thermal stability and the media (aqueous or non-aqueous) where the reaction is carried out [132]. Enzymatic saccharification of LCMs using MHP for fermentable sugar production is summarized in Table 4 .

Some works where combined pretreatments with MHP were used to produce high added-value products in terms of biorefinery are mentioned: Rorke et al. [139] obtained 21 volatile compounds from waste sorghum leaves pretreated with microwave assisted with $2.5 \% \mathrm{HCl}$ pretreatment They found aliphatic acids, 


\begin{tabular}{|c|c|c|c|c|c|c|}
\hline $\begin{array}{l}\text { Pretreatment used in } \\
\text { combination with MHP }\end{array}$ & Pretreatment best conditions reported & MHP conditions & Feedstock and particle size used & Raw material composition (\%) & $\begin{array}{l}\text { Material composition } \\
\text { after pretreatment (\%) }\end{array}$ & Reference \\
\hline Alkali & $\begin{array}{l}20 \mathrm{~g} \text { of biomass, } 160 \mathrm{ml} \text { of } 1 \% \mathrm{NaOH} \text { aqueous } \\
\text { solution }\end{array}$ & $700 \mathrm{~W}$ power for $30 \mathrm{~min}$ & Rice straw (1-2 cm length) & $\begin{array}{l}\text { Cellulose }(\mathrm{C}): 38.6 \text {; lignin } \\
\text { (L):13.6; hemicellulose }(\mathrm{H}): 19.7\end{array}$ & $\begin{array}{l}\text { C: } 69.2 \text {, } \\
\text { L: } 4.9 ; \\
\text { H: } 10.2\end{array}$ & [97] \\
\hline Alkali & $\begin{array}{l}20 \mathrm{~g} \text { of biomass } 160 \mathrm{ml} \text { of } 1 \% \mathrm{NaOH} \text { aqueous } \\
\text { solution }\end{array}$ & $700 \mathrm{~W}$ for $25 \mathrm{~min}$ & Wheat straw (1-2 cm lengths) & $\begin{array}{l}\text { C: } 41.2 ; \\
\text { L: } 21.3 ; \\
\text { H: } 25.8\end{array}$ & $\begin{array}{l}\text { C: } 79.6 ; \\
\text { L: } 5.7 ; \\
\text { H: } 7.8\end{array}$ & [98] \\
\hline Alkali & $50 \mathrm{~g} / \mathrm{L}$ of biomass load, $0.1 \mathrm{~g} / \mathrm{g}$ of alkali loading & $1000 \mathrm{~W}$ at $190^{\circ} \mathrm{C}$ for $30 \mathrm{~min}$ & Switchgrass $(425 \mu \mathrm{m})$ & $\begin{array}{l}\text { Glucan }(G n): 33.6 \\
\text { Xylan }(X n): 19.3 \\
\text { L:21.4 }\end{array}$ & $\begin{array}{l}\text { *Removed: L:82; } \\
\text { Xn: } 11.8 \\
\text { Gn:1.8 }\end{array}$ & [99] \\
\hline Alkali & $4 \mathrm{wt} \% \mathrm{NaOH}$ solution, 2.5:1 liquid/solid ratio & $\begin{array}{l}40^{\circ} \mathrm{C} \text { for } 24 \mathrm{~h} \text { followed by } \mathrm{MH} \\
450 \mathrm{~W} \text { for } 3 \mathrm{~min}\end{array}$ & Rice hulls $(1-2 \mathrm{~mm})$ & $\begin{array}{l}\text { Gn: } 37.49 \\
\text { Xn: } 15.68 \\
\text { L: } 23.11\end{array}$ & $\begin{array}{l}\text { Gn: } 49.77 \\
\text { Xn: } 22.93 \\
\text { L:20.76 }\end{array}$ & [56] \\
\hline Alkali & $3.5 \mathrm{~g}$ of biomass in $31.5 \mathrm{~g} \mathrm{NaOH}$ at $5 \%$ & $140^{\circ} \mathrm{C}$ for $10 \mathrm{~min}$ & Wheat straw (2 mm) & $\begin{array}{l}\text { G: } 35.7 \\
\text { X: } 9.8 \\
\text { A: } 1.43\end{array}$ & $\begin{array}{l}\text { *Removed: H:80; } \\
\text { L: } 90\end{array}$ & {$[100]$} \\
\hline Alkali & $\begin{array}{l}\text { Alkali at } 0.05 \% \text { with a soak time in alkali } 24 \mathrm{~h} \text {, } \\
\text { and } 30 \% \text { biomass loading }\end{array}$ & $300 \mathrm{~W}$ at $180^{\circ} \mathrm{C}$ for $6 \mathrm{~min}$ & Cotton plant $(1 \mathrm{~mm})$ & $\begin{array}{l}\text { C: } 38.26 \\
\text { H: } 13.7 \\
\text { L: } 29.95\end{array}$ & $\begin{array}{l}\text { C: } 42.37 \\
\text { H: } 2.81 \\
\text { L: } 2.12\end{array}$ & [101] \\
\hline Dilute Acid & $500 \mathrm{mg}$ of biomass, $50 \mathrm{ml}$ of $\mathrm{H}_{2} \mathrm{SO}_{4}$ at $5 \%(\mathrm{v} / \mathrm{v})$ & $700 \mathrm{~W}$ at $200^{\circ} \mathrm{C}$ for $5 \mathrm{~min}$ & Garden biomass $(1 \mathrm{~mm})$ & $\begin{array}{l}\text { C: } 39.57 \\
\text { H:26.55; } \\
\text { L:24.46 }\end{array}$ & $\begin{array}{l}\text { C: } 53.95 \\
\text { H: } 11.62 \\
\text { L: } 27.03\end{array}$ & [86] \\
\hline Dilute Acid & $\begin{array}{l}10 \mathrm{~g} \text { of biomass with } 200 \mathrm{ml} \text { of dilute sulfuric } \\
\text { acid solution at } 0.2 \mathrm{M}\end{array}$ & $\begin{array}{l}190^{\circ} \mathrm{C} \text { for } 5 \mathrm{~min} \text {, at less than } \\
900 \mathrm{~W}\end{array}$ & Sugarcane bagasse $(0.42 \mathrm{~mm})$ & $\begin{array}{l}\text { C: } 5245 ; \\
\text { H: } 25.97 \\
\text { L: } 1272\end{array}$ & $\begin{array}{l}\text { C: } 67.31 ; \\
\text { H: } 0.8 ; \\
\text { L: } 15.67\end{array}$ & [102] \\
\hline Dilute Acid & $\begin{array}{l}10 \mathrm{~g} \text { of biomass with } 100 \mathrm{ml} \text { dilute sulfuric acid } \\
\text { solution at } 0.005 \mathrm{M}\end{array}$ & $900 \mathrm{~W}$ at $180^{\circ} \mathrm{C}$ for $30 \mathrm{~min}$ & Sugarcane bagasse $(0.42 \mathrm{~mm})$ & $\begin{array}{l}\text { C: } 48.45 \\
\text { H: } 29.92 \\
\text { L: } 17.12\end{array}$ & $\begin{array}{l}\text { C: } 59.66 \\
\text { H: } 3.84 \\
\text { L: } 23.72\end{array}$ & [103] \\
\hline Diluid Acide & $1 \%$ sulfuric acid & $26 \mathrm{~W}$ at $140^{\circ} \mathrm{C}$ for $20 \mathrm{~min}$ & Corn stover (quarter inch) & $\begin{array}{l}\text { Gn: } 35.2 \\
\text { Xn: } 20.6 \\
\text { L: } 22.6\end{array}$ & L: $14.6 ;$ Gn: 31.7; Xn:1.0 & [85] \\
\hline Organic Acid & $\begin{array}{l}25 \% \text { acetic acid, } 1: 15 \text { solid/liquid ratio } \\
25 \% \text { propionic acid, } 1: 15 \text { solid/liquid ratio }\end{array}$ & $230 \mathrm{~W}$ for $5 \mathrm{~min}$ & $\begin{array}{l}\text { Rice Straw }(0.2 \mathrm{~mm} \text { aperture } \\
\text { size) }\end{array}$ & $\begin{array}{l}\text { C: } 41 \\
\text { H: } 20 \\
\text { L; } 17.8\end{array}$ & $\begin{array}{l}{ }^{*} \text { Removed L; } 46.1 \\
{ }^{*} \text { Removed L; } 51.54\end{array}$ & [104] \\
\hline $\begin{array}{l}\text { Organosolv with acid } \\
\text { catalysts }\end{array}$ & $\begin{array}{l}10 \% \text { glycerol/water solution was used as a } \\
\text { solvent in liquid/solid ratio of } 17: 1(\mathrm{w} / \mathrm{w}), 0.1 \% \\
(\mathrm{w} / \mathrm{w}) \text { hydrochloric acid }\end{array}$ & Batch reactor at $180^{\circ} \mathrm{C}$ for $6 \mathrm{~min}$ & $\begin{array}{l}\text { Softwood (2-6 mm long, } 2- \\
4 \mathrm{~mm} \text { wide and } 1-3 \mathrm{~mm} \text { thick) }\end{array}$ & $\begin{array}{l}\text { C: } 47.8 \\
\text { H:20.3; } \\
\text { L: } 31.0\end{array}$ & L: 25.6 & [105] \\
\hline $\begin{array}{l}\text { Ammonium molybdate } \\
\text { activated by } \mathrm{H}_{2} \mathrm{O}_{2}\end{array}$ & $1 \mathrm{mM}$ of ammonium molybdate, $0.88 \mathrm{M} \mathrm{H}_{2} \mathrm{O}_{2}$ & $\begin{array}{l}400 \mathrm{~W} \text { at } 140{ }^{\circ} \mathrm{C} \text { for } 30 \mathrm{~min} \text { with } \\
\text { constant stirring at } 900 \mathrm{rpm}\end{array}$ & Beech wood $(0.425-0.6 \mathrm{~mm})$ & $\begin{array}{l}\text { L: } 23 ; \\
\text { C: } 49.9\end{array}$ & L: $3.7 ;$ C:73.2 & [79] \\
\hline Autohydrolysis & $75 \mathrm{~g} / \mathrm{L}$ of substrate loading & $680 \mathrm{~W}$ for $24 \mathrm{~min}$ & Rice straw $(450 \mu \mathrm{m})$ & $\begin{array}{l}\text { C: } 33.4 \\
\text { H: } 16.2 \\
\text { L: } 6.8\end{array}$ & $\begin{array}{l}\text { C: } 41.8 \\
\text { L: } 6.9 ; \\
\text { H: } 23.6\end{array}$ & [106] \\
\hline Autohydrolysis & $5 \%$ solids load in $10 \mathrm{ml}$ of water & $75 \mathrm{~W}$ at $180^{\circ} \mathrm{C}$ for $20 \mathrm{~min}$ & Corn stover $(0.635)$ & $\begin{array}{l}\text { L: } 22.6 \\
\text { Gn: } 35.2 \\
\text { Xn: } 20.6\end{array}$ & $\begin{array}{l}\text { L: } 17.1 \\
\text { Gn: } 32.7 \\
\text { Xn: } 3.6\end{array}$ & [85] \\
\hline Lime & $0.1 \mathrm{~g}$ lime, $10: 1 \mathrm{~L} / \mathrm{S}$ ratio & $1000 \mathrm{~W}$ for $4 \mathrm{~min}$ & $\begin{array}{l}\text { Sweet sorghum bagasse } \\
(1-2 \mathrm{~mm})\end{array}$ & $\begin{array}{l}\text { C: } 36.9 \\
\text { H: } 17.8 \\
\text { L: } 19.5\end{array}$ & *Removed L: 39; H: 20 & {$[107]$} \\
\hline Steam Explosion & $100 \mathrm{~g}$ of material with $15 \mathrm{~L}$ saturated steam & $540 \mathrm{~W}$ for $5 \mathrm{~min}$ & Corn stover $(6-20 \mathrm{~mm})$ & $\begin{array}{l}\text { Gn: } 57 \\
\text { Xn: } 9.9 \\
\text { L: } 25.8\end{array}$ & $\begin{array}{l}\text { Gn: } 30.3 ; \\
\text { Xn: } 13.3 \\
\text { L: } 17.2\end{array}$ & [108] \\
\hline Steam Explosion & $\begin{array}{l}100 \mathrm{~g} \text { of material with } 15 \mathrm{~L} \text { saturated steam at } \\
1.45 \mathrm{MPa} \text { pressure of saturated steam }\end{array}$ & $540 \mathrm{~W}$ for $5 \mathrm{~min}$ at $200{ }^{\circ} \mathrm{C}$ & Corn stover $(6-20 \mathrm{~mm})$ & $\begin{array}{l}\text { Gn: } 57 ; \\
\text { Xn: } 9.9 ; \\
\text { L: } 25.8\end{array}$ & $\begin{array}{l}\text { Gn: } 23.8 \\
\text { Xn } 3.2 \\
\text { L: } 10.1\end{array}$ & [109] \\
\hline Immersion with $\mathrm{CaCl}_{2}$ & $10 \%$ solid (w/v) with $300 \mathrm{~mL}$ of $\mathrm{CaCl}_{2}$ solution & $800 \mathrm{~W}$ for $12 \mathrm{~min}$ at $162{ }^{\circ} \mathrm{C}$ & Corn stover $(2 \mathrm{~mm})$ & C: 23.93; & C: 47.10 ; & [85] \\
\hline
\end{tabular}


aldehydes and ketones, as well as lower amounts of alcohols, lactones and aromatic compounds, including reducing sugars $(9.13 \mathrm{~g} / \mathrm{L})$, acetic acid (186.26 ng/g), furfural $(240.80 \mathrm{ng} / \mathrm{g})$, 5-hydroxymethylfurfural (19.20 ng/g) and phenol (7.76 ng/g).

Zhang and Zhao [140] studied the production of HMF and furfural (building block among the top 10 bio-based chemicals) from corn stalk, rice straw and pine wood treated by ionic liquid in the presence of $\mathrm{CrCl}_{3}$ under microwave irradiation (650 W for $3 \mathrm{~min}$ ), results showed HMF and furfural yields of $45-52 \%$ and $23-31 \%$, respectively. Lacerda et al. [141] studied the production of HMF and furfural from carnauba palm laves, macauba pulp and shell and pine nut shell. They conclude that temperature and time are two crucial parameters significantly influence the LCM hydrolysis. Other high value products reported are: xylooligosaccharides [142], pectin from fruit rinds [143], phenol and phenolic compounds by catalytic microwave pyrolysis [144], lignin with antioxidant activity from birch [145]. Besides, it has been tested to enhance anaerobic digestibility in methane production using switchgrass [146] and the lignin liquefaction to obtain polyols with high content of reactive hydroxyl groups [147].

\section{Energy consumption of microwave heating in pretreatments}

The energy expenditure in the pretreatment raises considerably the total cost of bioethanol production, for this reason is a critical factor to consider in biorefinery processes. Best pretreatments promise to ensure a low production cost on industrial scale. MHP could be a good equipment to reduce energy consumption because it has been described as a technology with energy efficiency [127]. The MHP has a better energy efficiency in the process of water removal it was reported 22.5 times higher than conventional heating [148]. Xia et al. [76] demonstrated that MHP dramatically reduces the pretreatment time by a factor of over 10. Energy input for microwave-acid pretreatment using $20 \mathrm{~g} / \mathrm{L}$ of water hyacinth with $1 \% \mathrm{H}_{2} \mathrm{SO}_{4}$ at $140{ }^{\circ} \mathrm{C}$ for $15 \mathrm{~min}$ was also calculated with energy waste of $11.8 \%$. (Microwave input power starts up with $48.0 \mathrm{~kJ}$ and the energy output from bioethanol produced was $407.1 \mathrm{~kJ})$. Therefore, they concluded that it is necessary to develop a continuous microwave system to reuse the waste heat and decrease energy input of pretreatment for large-scale application.

Wang et al. [89] reported an energy expenditure of $192 \mathrm{~kJ}$ using MHP in ionic liquids pretreatment for wood delignification. Their results were compared with oil bath heating that spent $560 \mathrm{~kJ}$. Further, the lignin content in the wood pretreated by microwave was much lower than lignin from oil bath heating treatment.

Lu et al. [117] estimated the energy consumption in the pretreatment of rape straw using $10 \%$ of solid loading, for 3 and $6 \mathrm{~min}$ at $700 \mathrm{~W}$ and $10 \mathrm{~min}$ at $900 \mathrm{~W}$, the energy consumption was $67.2,153.9$ and $169.2 \mathrm{~kJ}$ respectively to produce $1 \mathrm{~g}$ of glucose and $105.4,230.7$ and $235.2 \mathrm{~kJ}$ to produce $1 \mathrm{~g}$ of ethanol. The most energy consumed is used in the water evaporation. This phenomenon requires $2.5 \mathrm{~kJ}$ per gram of evaporated water at $25^{\circ} \mathrm{C}$, water evaporation resulted in energy expenditure of $92.8,172.3$ and $213.8 \mathrm{~kJ}$ respectively which represents from 48 to $64 \%$ of the total consumption of the process. Vani et al. [101] compared the energy consumption between alkaline pretreatment assisted with microwave heating processing and high pressure pretreatment using as substrate cotton plant residue. Microwave pretreatment was carried out with a loading of $17.5 \% \mathrm{w} / \mathrm{v}$ at $300 \mathrm{~W}$ for $6 \mathrm{~min}$ and high pressure pretreatment with load of $5 \% \mathrm{w} / \mathrm{v}$ at $180^{\circ} \mathrm{C}$ and $100 \mathrm{rpm}$ for $45 \mathrm{~min}$. Results showed total energy consumption with MHP was $108 \mathrm{~kJ}$ whereas high pressure pretreatment consumption was $540 \mathrm{~kJ}$, this means 5 times more energy.

Marx et al. [121] reported a lower power input $(43.2 \mathrm{~kJ} / \mathrm{g}$ of dry sweet sorghum bagasse) using acid pretreatment at $5 \%$ at $180 \mathrm{~W}$ 
Table 3

MHP in combination with others pretreatments for bioethanol production from LCMs.

\begin{tabular}{|c|c|c|c|c|c|c|c|}
\hline $\begin{array}{l}\text { Pretreatment used in } \\
\text { com-bination with } \\
\text { MHP }\end{array}$ & Pretreatment conditions & $\begin{array}{l}\text { MHP } \\
\text { conditions }\end{array}$ & $\begin{array}{l}\text { Feedstock and } \\
\text { particle size used }\end{array}$ & $\begin{array}{l}\text { Untreated material composition (UMC) and } \\
\text { composition material after pretreatment } \\
\text { (TMC) (\%) }\end{array}$ & $\begin{array}{l}\text { Sugar yields (SY) in } \\
\text { enzymatic } \\
\text { hydrolysis }\end{array}$ & $\begin{array}{l}\text { Ethanol yield (EY) and } \\
\text { ethanol concentration } \\
\text { (EC) }\end{array}$ & Reference \\
\hline Acid & $0.5 \% \mathrm{H}_{2} \mathrm{SO}_{4}$ & $\begin{array}{l}200{ }^{\circ} \mathrm{C} \text { for } \\
5 \mathrm{~min}\end{array}$ & Barley husk & $\begin{array}{l}\text { UMC; Gn: } 30.1 ; \mathrm{Xn}: 28.7 ; \text { A: } 6.2 \\
\text { TMC; G: 85; X: 46; A: } 52\end{array}$ & $85 \%$ & $\begin{array}{l}\mathrm{EY}=81 \% \\
\mathrm{EC}=15 \mathrm{~g} / \mathrm{L}\end{array}$ & [116] \\
\hline Acid & $\begin{array}{l}10 \mathrm{~g} \text { of straw, } 90 \mathrm{~g} \text { of } 2 \%(\mathrm{v} / \mathrm{v}) \mathrm{H}_{2} \mathrm{SO}_{4} \text {, solid loading of } \\
30 \%\end{array}$ & $\begin{array}{l}900 \mathrm{~W} \text { for } \\
1 \mathrm{~min}\end{array}$ & $\begin{array}{l}\text { Rape straw }(1 \mathrm{~cm} \\
\text { in length) }\end{array}$ & $\begin{array}{l}\text { UMC: C: } 37.0 ; \mathrm{H}: 19.6 ; \text { L: } 18.0 \\
\text { TMC: C:42.3; H: 23.6; L: } 15.4\end{array}$ & $56.2 \%$ & $\begin{array}{l}E Y=65 \% \\
E C=13.6 \mathrm{~g} / 1\end{array}$ & [117] \\
\hline $\begin{array}{l}\text { Biological- } \\
\quad \text { Hydrothermal }\end{array}$ & $\begin{array}{l}\text { C. Subvermispora ATCC } 90467 \text { was incubed at } 28^{\circ} \mathrm{C} \\
\text { and } 70 \% \text { moisture for } 8 \text { weeks, followed by } \\
\text { microwave hydrothermal pretreatment } 0.6 \mathrm{~g} \text { in } \\
20 \mathrm{ml} \text { (solid/liquid) }\end{array}$ & $\begin{array}{l}200^{\circ} \mathrm{C} \text { for } \\
10 \mathrm{~min}\end{array}$ & $\begin{array}{l}\text { Sugarcane } \\
\text { bagasse }(1-3 \mathrm{~cm} \\
\text { in length) }\end{array}$ & $\begin{array}{l}\text { UMC: C:42.2; H:70.4; L: } 27.9 \\
\text { "Removed: L: 20.4; C: } 5.5\end{array}$ & $89 \%$ & $\begin{array}{l}\mathrm{EY}=35.8 \% \\
\mathrm{EC}=15.4 \mathrm{~g} / \mathrm{L}\end{array}$ & [118] \\
\hline Dilute ammonia & $28 \%$ ammonium hydroxide solution $(\mathrm{v} / \mathrm{v})$ and water & $130^{\circ} \mathrm{C}$ for $1 \mathrm{~h}$ & $\begin{array}{l}\text { Sweet sorghum } \\
\text { bagasse }(1- \\
2 \mathrm{~mm})\end{array}$ & $\begin{array}{l}\text { UMC: Gn: 45; Xn: 28; L: } 22 \\
\text { TMC: G: 42; X:19; L: } 12.37\end{array}$ & $\begin{array}{l}4.2 \mathrm{~g} \text { of glucose/ } \\
10 \mathrm{~g} \text { dry biomass }\end{array}$ & $\begin{array}{l}\mathrm{EY}=2.1 \mathrm{~g} / 10 \mathrm{~g} \text { dry } \\
\text { biomass }\end{array}$ & [119] \\
\hline Alkali & $\begin{array}{l}2.75 \% \text { alkali concentration, } 30 \mathrm{~g} / \mathrm{L} \text { substrate } \\
\text { concentration, ratio } 10: 1 \text { liquid/solid }\end{array}$ & $\begin{array}{l}800 \mathrm{~W} \text { at } \\
100^{\circ} \mathrm{C} \text { for }\end{array}$ & Rice husk (1 mm) & $\begin{array}{l}\text { UMC: C: } 35 ; \mathrm{H}: 13 ; \mathrm{L}: 15.2 \\
\text { TMC: C:46; H:20; L: } 7.2\end{array}$ & $62.1 \%$ & $\begin{array}{l}E Y=82 \% \\
E C=12.6 \mathrm{~g} / \mathrm{L}\end{array}$ & [120] \\
\hline Alkali & & $22.5 \min$ & $\begin{array}{l}\text { Rice straw } \\
(1 \mathrm{~mm})\end{array}$ & $\begin{array}{l}\text { UMC: C: } 38 ; \mathrm{H}: 26 ; \mathrm{L}: 7 \\
\text { TMC: C: } 52 ; \mathrm{H}: 32 ; \mathrm{L}: 3.5\end{array}$ & $74.1 \%$ & $\begin{array}{l}\mathrm{EY}=75.14 \% \\
\mathrm{EC}=19.2 \mathrm{~g} / \mathrm{L}\end{array}$ & [34] \\
\hline Acid & $0.05 \%$ sulphuric acid & $\begin{array}{l}180 \mathrm{~W} \text { for } \\
20 \mathrm{~min}\end{array}$ & $\begin{array}{l}\text { Sweet sorghum } \\
(1.5 \mathrm{~mm})\end{array}$ & $\begin{array}{l}\text { UMC: C: 36.60; H: 22.96: Acid lignin } 5.90 \\
\text { TMC: NR }\end{array}$ & $\begin{array}{l}\text { C; } 100 \% \text { and } \mathrm{H}: \\
58.5 \%\end{array}$ & $\mathrm{EY}=94 \%$ & [121] \\
\hline Alkali & $\begin{array}{l}28^{\circ} \mathrm{C} \text { for } 10 \mathrm{~min} \text { with a solution of } 0.2 \mathrm{~mol} / \mathrm{l} \mathrm{NaOH} \\
\text { at } \mathrm{L} / \mathrm{S} \text { ratio of } 10: 3(\mathrm{v} / \mathrm{w})\end{array}$ & $\begin{array}{l}600 \mathrm{~W} \text { for } \\
15 \mathrm{~min}\end{array}$ & $\begin{array}{l}\text { Cashew apple } \\
\text { bagasse (20\# } \\
\text { mesh) }\end{array}$ & UMC: C: 19.21; H: 12.05; L: 38.11 & $\begin{array}{l}372 \mathrm{mg} \text { glucose } / g \\
\text { glucan }\end{array}$ & $\begin{array}{l}\mathrm{EY}=93.9 \% \\
\mathrm{EC}=5.6 \mathrm{~g} / \mathrm{L}\end{array}$ & [122] \\
\hline Alkali & $\begin{array}{l}1: 10 \text { ratio of } 1 \%(\mathrm{w} / \mathrm{v}) \mathrm{NaOH} \text { after MHP biomass was } \\
\text { neutralized and dried then was immersed in } 1 \%(\mathrm{v} / \\
\mathrm{v}) \mathrm{H}_{2} \mathrm{SO}_{4} \text { to achieve a liquid-to-solid ratio of } 10: 1(\mathrm{v} / \\
\text { w) for } 1 \mathrm{~h}\end{array}$ & $\begin{array}{l}850 \mathrm{~W} \text { at } \\
150^{\circ} \mathrm{C} \text { for } \\
3 \mathrm{~min}\end{array}$ & $\begin{array}{l}\text { Rice Straw } \\
(0.5 \mathrm{~mm})\end{array}$ & $\begin{array}{l}\text { UMC: C: } 42.54 ; \mathrm{H}: 14.9 ; \mathrm{L}: 4.52 \\
\text { TMC: C:46.07 H:20; L: } 7.2\end{array}$ & 36.91 & $\begin{array}{l}\mathrm{EY}=46.9 \% \\
\mathrm{EC}=16.2 \mathrm{~g} / \mathrm{L}\end{array}$ & [94] \\
\hline Acid & $3 \%(\mathrm{v} / \mathrm{v}) \mathrm{H}_{2} \mathrm{SO}_{4}$ at $\mathrm{L} / \mathrm{S}$ ratio of $4: 1(\mathrm{w} / \mathrm{w})$ & $1100 \mathrm{~W}$ for 3 & Sago bark waste & & $\begin{array}{l}62.6 \% \text { maximum } \\
\text { sugar yield }\end{array}$ & $\begin{array}{l}\mathrm{EY}=60.2 \% \\
\mathrm{EC}=30.67 \mathrm{~g} / 1\end{array}$ & [123] \\
\hline
\end{tabular}


Table 4

Enzymatic saccharification of LCMs using MHP in combination with others pretreatments for fermentable sugars production.

\begin{tabular}{|c|c|c|c|c|c|}
\hline $\begin{array}{l}\text { Pretreatment } \\
\text { used in } \\
\text { combination } \\
\text { with MHP }\end{array}$ & Pretreatment conditions & Feedstock & Enzymatic Saccharification conditions & $\begin{array}{l}\text { Sugar yield (SY) } \\
\text { or sugar } \\
\text { concentration } \\
\text { (SC) }\end{array}$ & Reference \\
\hline Alkali & $\begin{array}{l}\mathrm{L} / \mathrm{S} \text { ratio of } 20: 1(\mathrm{v} / \mathrm{w}), 1 \% \mathrm{NaOH}, 200^{\circ} \mathrm{C} \\
\text { for } 5 \text { min }\end{array}$ & $\begin{array}{l}\text { Green tea } \\
\text { residue }\end{array}$ & Cellulase (Meicelase) $1.0 \%(\mathrm{w} / \mathrm{w})$ at $37^{\circ} \mathrm{C}$ for $48 \mathrm{~h}$ & $\mathrm{SY}=89 \%$ & [75] \\
\hline Inorganic salt & $\begin{array}{l}\mathrm{L} / \mathrm{S} \text { ratio of } 10: 10.09(\mathrm{v} / \mathrm{w}) \text { and } \\
0.14 \mathrm{~mol} / 1 \mathrm{FeCl}_{3}, 160^{\circ} \mathrm{C} \text { for } 19 \mathrm{~min} \text {, }\end{array}$ & Rice straw & $\begin{array}{l}\text { Bacillus pumilus spore }(1 \mathrm{ml} / 100 \mathrm{ml} \text { medium }) \text {, } \\
\text { Trichoderma viride spore }(2 \mathrm{ml} / 100 \mathrm{ml} \text { medium }) \text { at } 30^{\circ} \mathrm{C} \\
\text { for } 72 \mathrm{~h}\end{array}$ & $\begin{array}{l}\mathrm{SC}=6.62 \mathrm{~g} / \mathrm{l} \\
\text { reducing sugars }\end{array}$ & [133] \\
\hline Ionic liquid & $\begin{array}{l}\mathrm{L} / \mathrm{S} \text { ratio of } 20: 1[\mathrm{C} \mathrm{mim}][\mathrm{OAc}] 4 \text { at } \\
200 \mathrm{~W}\end{array}$ & $\begin{array}{l}\text { Rubber } \\
\text { wood } \\
\text { biomass }\end{array}$ & $\begin{array}{l}\text { Cellulase (Spezyme CP) } 52 \mathrm{FPU} / \mathrm{g} \text { glucan, } \beta \text {-glucosidase } \\
\text { (Novozyme 188) } 130 \mathrm{CBU} / \mathrm{g} \text { glucan at } 48{ }^{\circ} \mathrm{C} \text { for } 72 \mathrm{~h}\end{array}$ & $\mathrm{SY}=52 \%$ glucose & [127] \\
\hline \multirow[t]{2}{*}{ Dilute alkali } & $\begin{array}{l}\mathrm{L} / \mathrm{S} \text { ratio of } 1: 10,2 \% \mathrm{NaOH}, 0.250 \mathrm{~W} \text { for } \\
10 \mathrm{~min}\end{array}$ & Switchgrass & \multirow[t]{2}{*}{$\begin{array}{l}\text { Cellulase (Celluclast } 1.5 \mathrm{~L} \text { ) } 40 \mathrm{FPU} / \mathrm{g} \text { biomass } 55^{\circ} \mathrm{C} \text { and } \\
150 \mathrm{rpm}, \mathrm{pH} \text { of } 4.8\end{array}$} & $\begin{array}{l}\mathrm{SY}=82 \% \text { glucose } \\
\text { yield and } 63 \% \\
\text { xylose yield }\end{array}$ & \multirow[t]{2}{*}{ [134] } \\
\hline & $\begin{array}{l}\mathrm{L} / \mathrm{S} \text { ratio of } 1: 10,1 \% \mathrm{NaOH}, 250 \mathrm{~W} \text { for } \\
10 \mathrm{~min}\end{array}$ & $\begin{array}{l}\text { Bermuda } \\
\text { grass coast }\end{array}$ & & $\begin{array}{l}\text { SY }=87 \% \text { of } \\
\text { glucose and } 59 \% \\
\text { xylose yield }\end{array}$ & \\
\hline \multirow[t]{2}{*}{ Aqueos glycerol } & $\begin{array}{l}\mathrm{L} / \mathrm{S} \text { ratio of } 1: 6,95 \%(\mathrm{v} / \mathrm{v}) \text { glycerol- } \\
\text { water, } 1300 \mathrm{~W} \text { for } 2 \mathrm{~min} \text { at } 180^{\circ} \mathrm{C}\end{array}$ & Corn straw & $\begin{array}{l}0.3 \mathrm{~g} \text { of solid in } 7 \mathrm{~mL} \text { of medium, } 15.7 \% \mathrm{v} / \mathrm{v} \text {, crude } \\
\text { enzyme extract }(137 \mathrm{IU} / \mathrm{g}) \text { and commercial BGL }\end{array}$ & $S Y=20.69 \%$ & \multirow[t]{2}{*}{ [135] } \\
\hline & $\begin{array}{l}\mathrm{L} / \mathrm{S} \text { ratio of } 1: 6,95 \%(\mathrm{v} / \mathrm{v}) \text { glycerol- } \mathrm{NaOH} \\
1.4 \mathrm{M}, 1300 \mathrm{~W} \text { for } 2 \mathrm{~min} \text { at } 180^{\circ} \mathrm{C}\end{array}$ & Rice husk & (Novozymes) $70 \mathrm{IU} / \mathrm{g}$ at $55^{\circ} \mathrm{C}$ and $150 \mathrm{rpm}$ for $72 \mathrm{~h}$ & $\mathrm{SY}=32.89 \%$ & \\
\hline Ionic liquids & $\begin{array}{l}5 \mathrm{~g} \text { of kenaf/IL mixture ChOAc and } \\
\text { ChPro, } 110^{\circ} \mathrm{C} \text { for } 20 \text { min at } 100 \mathrm{~W} \\
1200 \mathrm{rpm}\end{array}$ & $\begin{array}{l}\text { Kenaf } \\
\text { powder }\end{array}$ & $\begin{array}{l}50{ }^{\circ} \mathrm{C} \text { at } 130 \mathrm{rpm}, 0.03 \mathrm{~g} \text { of kenaf powder in } 5 \mathrm{~mL} \text { of } \\
\text { medium, cellulase } 62 \mathrm{FPU} / \mathrm{mL} \text {, pH } 5.0 \text { for } 48 \mathrm{~h}\end{array}$ & SY = almost $90 \%$ & [136] \\
\hline $\mathrm{Ca}(\mathrm{OH})_{2}$ & $2.25 \%$ of $\mathrm{Ca}(\mathrm{OH})_{2}(\mathrm{w} / \mathrm{v}), 400 \mathrm{~W}$ for $6 \mathrm{~min}$ & $\begin{array}{l}\text { Catalpa } \\
\text { sawdust }\end{array}$ & $50^{\circ} \mathrm{C}$ for $48 \mathrm{~h}$ at $100 \mathrm{rpm}$, cellulase $175 \mathrm{FPU} / \mathrm{g}$, & $\begin{array}{l}\mathrm{SC}=402.73 \mathrm{mg} / \\
\mathrm{g}\end{array}$ & [137] \\
\hline Glycerol & $\begin{array}{l}\text { First mixture was immersed in glycerol } \\
(100 \%) \text { for } 24 \mathrm{~h}, \mathrm{~S} / \mathrm{L} \text { ratio of } 1: 3 \text {, then } \\
\text { was applied } \mathrm{MH} \text { for } 5 \mathrm{~min}\end{array}$ & $\begin{array}{l}\text { Sugarcane } \\
\text { bagasse }\end{array}$ & $\begin{array}{l}55^{\circ} \mathrm{C} \text { for } 24 \mathrm{~h} \text { at } 150 \mathrm{rpm}, 500.0 \mathrm{U} / \mathrm{g} \text { endoglucanase, } \\
156.6 \mathrm{U} / \mathrm{g} \beta \text {-glucosidase and } 78.3 \mathrm{U} / \mathrm{g} \text { xylanase }\end{array}$ & $\begin{array}{l}\mathrm{SC}=20.3 \mathrm{mg} / \mathrm{g} \\
\text { xylose, } \\
237.5 \mathrm{mg} / \mathrm{g} \\
\text { glucose }\end{array}$ & [138] \\
\hline
\end{tabular}

for $20 \mathrm{~min}$ to produce $82 \mathrm{~g}$ of reducing sugars/100 $\mathrm{g}$ of sorghum bagasse were obtained after enzymatic hydrolysis.

Besides, it was observed that a large amount of energy consumed occurs during heating to reach the required temperature. Maximum energy yield was reported at $130^{\circ} \mathrm{C}$ with expenditure of 15-18 kJ, where grinding energy consumption of smaller particle sizes is rewarded with increased ethanol yield, also the amount of water in the pretreatment could be reduced, accordingly it would reduce energy consumption. Limayem and Ricke [149] considered the pretreatment energy efficiency as total sugar recovery $(\mathrm{kg}) /$ total energy consumption (MJ), they showed steam explosion consumed the highest level of energy and therefore the efficiency ratio is the lowest $(0.26 \mathrm{~kg}$ sugar/MJ) when compared to organosolv that presents $0.31-0.40 \mathrm{~kg}$ sugar $/ \mathrm{MJ}$ ) and sulfite pretreatment (SPORL) $0.35-043 \mathrm{~kg}$ sugar/MJ. In this sense MHP energy efficiency can be calculated and obtain a comparison pattern.

Biomass reactor loading is a major factor in the reduction energy consumptions. High solids loading is an operational strategy that allows higher yields of products with lower operating costs. Nevertheless, it is necessary suitable pretreatment conditions due to agitation problems with high loading substrate [150,151]. According to Vani et al. [101] for a cost-effective process the biomass loading in the microwave reactor should be more than $20 \%$. Kannan et al. [123] reported the lowest energy consumption using $40 \%(\mathrm{w} / \mathrm{w})$ of biomass loading and energy input of $33 \mathrm{~kJ}$ $(1100 \mathrm{~W}$ for $30 \mathrm{~s})$. In this process $1.27 \mathrm{~kJ}$ were required to produce $1 \mathrm{~g}$ of sugar after enzymatic hydrolysis and $1.76 \mathrm{~kJ}$ for $1 \mathrm{~g}$ ethanol after fermentation. They concluded that MHP in bioethanol production succeeded in $80 \%$ energy savings compared to rape straw by microwave pretreatment previously reported.

On the other hand, Pang et al. [109] performed an economic analysis of steam explosion assisted with MHP pretreatment using corn stover, they considered the pretreatment time in the analysis. The cost of produced sugars was reported in $0.093 \mathrm{US}$ dlls $/ \mathrm{kg}$ of sugars and the pretreatment resulted economically viable.
Although, microwave pretreatment has a higher investment, its operation cost is lower compared with conventional heating; this fact allows fast recovery of capital investment [101]. Furthermore, maintenance costs are lower and there is a commercial scale process improvement. The microwave pretreatment is economic and it has energy efficiency. Thus, this can be considered as viable technology with a promising future.

\section{Microwave heating reactors}

Microwave equipment consists in four basic parts: (i) Generator that provides electromagnetic energy to the samples; the most used is the magnetron. Magnetron is a cylinder, which contains an anode and a cathode; it is heated by high voltage with a strong magnetic field; (ii) Cavities have function as electrical oscillator in a specific frequency. Electrons move from cathode to the anode, accelerated by the potential difference between them; (iii) Waveguide is the medium where the waves are conveyed traveling from the generator to the channel which is responsible for transporting the waves from the generator to the applicator; (iv) Applicator is a system designed to ensure that the energy is transferred from the magnetron until it reaches the sample. It does not have specific dimensions; they depend on the frequency of transported waves. Currently, there are equipment with multimode and single-mode applicators [152]; (v) Resonator or cavity is workplace where the materials are exposed to microwaves, there are variations of cavities in the reactors these depend on the manufacturer and their application. The newest equipment has a control monitoring system of power, temperature and pressure [153].

Multimode microwave reactors (Fig. 3) possess a larger cavity in relation with the wave length and samples [154]. Microwaves coming into the cavity are reflected on the walls and repeatedly bounce before passing into the product, this phenomenon usually happening over thousand times in a domestic oven, increasing a 


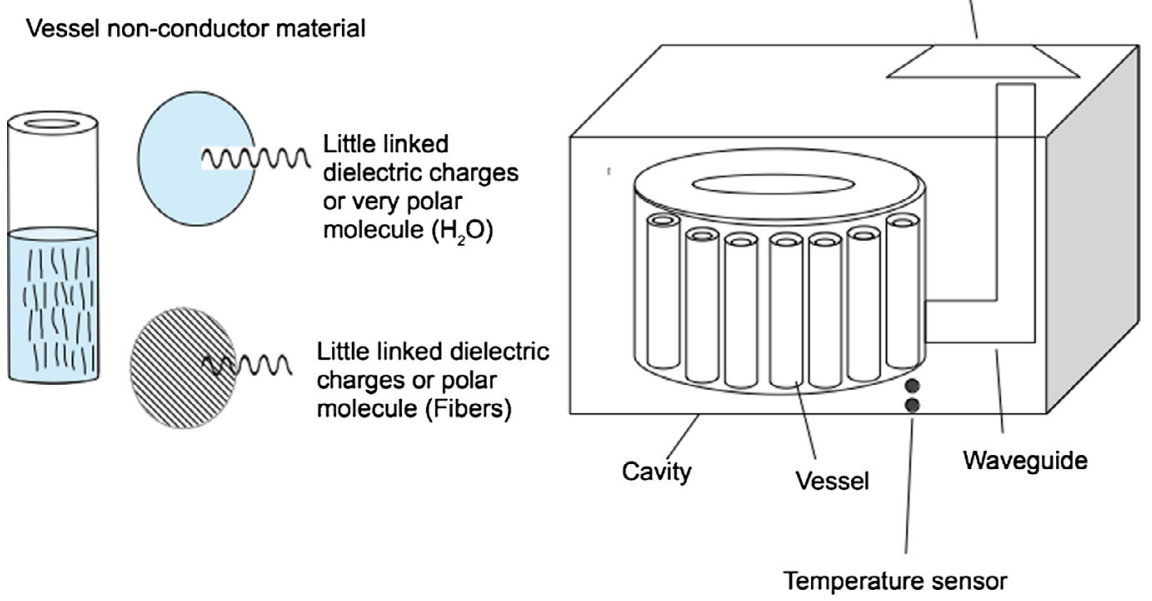

Fig. 3. Multimode microwave reactor diagram.

reflection mode that avoids the wave's orientation into the sample. Today two magnetrons are used in the reactors to maximize the homogeneity $[155,156]$. Multimode reactors have several advantages due to the possibility to homogenize the electromagnetic field with rotating devices (i.e. mode stirrers). They have the possibility of installing multiple microwave inlet ports, are cheaper than monomode reactor. It has large dimensions equipment that allows working with higher volumes. As a disadvantage these reactors do not presents an analytical solution with the Maxwell equations due to solution of the Maxwell equations describing the electromagnetic field in the case of partially loaded applicators and the need for thermal insulation over large areas. Maxwell's equations provide an exact solution for the propagation of microwave radiation within the samples [27].

Monomode microwave reactors or focused (Fig. 4) targeted the microwaves through a waveguide to reach the sample; this has a width as required by the wavelength, increasing the effectiveness of radiation, with the advantage of directing the wave to the material. Focused reactors have the possibility for constant power and temperature control, the energy has an uniform distribution of radiation since is more homogeneous throughout the cavity and then more reproducible results are generated. Monomode reactors are easier to design and present availability of analytical solutions.

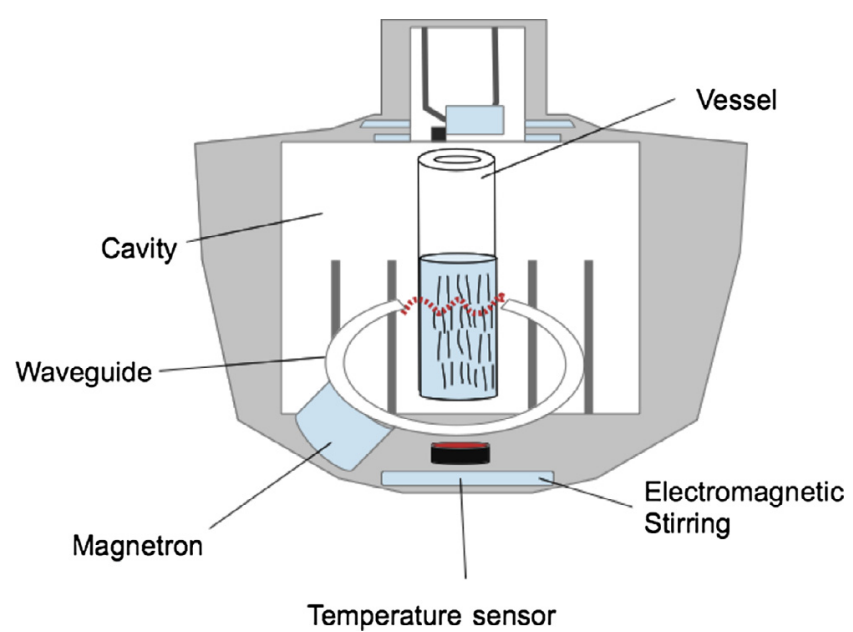

Fig. 4. Monomode microwave reactor diagram.
However, they have small dimensions and have a high production cost per load volume $[43,157]$. In Table 5 various types of microwave reactors available in market are shown.

On the other hand, the business perspective and scalability of microwave technology has been little studied, it would be convenient to study more to get a scale microwave continuous reactor. Filly et al. [162] developed oils extraction with microwave reactor. Results showed that this process maintains good product yields and the oils extraction can be comparable with the lab scale experiments. Peng et al. [164] developed the first reactor for LCM pretreatment in a pilot-scale continuous microwave irradiation. The reactor has a size of $3 \mathrm{~m}$ length $\times 0.760 \mathrm{~m}$ width $\times 1.750 \mathrm{~m}$ height; the maximum work temperature is $300{ }^{\circ} \mathrm{C}$ with a maximum pretreatment capacity of $5 \mathrm{~kg} / \mathrm{h}$. Optimal pretreatment conditions using corn stover were obtained with $4.50 \mathrm{~kW}, 30 \mathrm{~min}$, and $3.50 \%$ $\mathrm{NaOH}(\mathrm{w} / \mathrm{v})$, the glucose and ethanol production were 63.22 and $31.29 \mathrm{~g} / 100 \mathrm{~g}$ of pretreated dry material.

Likewise, Périno et al. [165] reported the pilot-scale process for polyphenols extraction with MHP on lettuce using a MAC-75 multimode microwave reactor equipped with 4 magnetrons (4 $1500 \mathrm{~W}, 2450 \mathrm{MHz}$ ) with a maximum power of $6000 \mathrm{~W}$ its capacity is of $150 \mathrm{~L}$ and contains a removable, rotating PTFE drum that allows up to $75 \mathrm{~L}$ of plant material to be loaded.

\section{Future perspectives}

Biofuels production from renewable sources such as $2 \mathrm{G}$ bioethanol is present as possible solution to substitution of fossil fuels that could to assure the energy supply of the planet. Therefore the identification of suitable pretreatment processing is a field with challenges and wide necessity research on development of integrated biorefineries. Recently, the numbers of publications, patents, applications and researches in the use of MHP have grown. This fact is due to MHP can be considered as a handy and environmentally friendly technology. Moreover, MHP has potentially improvements over conventional heating reactions that have led to high yields and process time reductions. Currently there are studies about the drying and extraction systems in scaling pilot using MHP. Nevertheless, there are few studies on the use of microwave reactors for LCMs pretreatments to pilot or industrial scale being necessary to devote efforts in this area.

In this way, it is necessary the development of systems and microwave reactors to operate at high loads and high pressures, 
Table 5

Microwave reactors available in market

\begin{tabular}{|c|c|c|c|c|c|}
\hline Brand & Model and type & Volume capacity & Power capacity & Reported uses & Reference \\
\hline Anton paar & Multiwave 3000 multimode & $16 \times 100 \mathrm{ml}$ & $1400 \mathrm{~W}$ & $\begin{array}{l}\text { Digestion, drying, leaching, evaporation, } \\
\text { extraction }\end{array}$ & [158] \\
\hline Anton paar & Monowave 300 monomode & $24 \times 30 \mathrm{ml}$ & $850 \mathrm{~W}$ & $\begin{array}{l}\text { Organic synthesis, inorganic synthesis, } \\
\text { material science, polymer chemistry }\end{array}$ & [159] \\
\hline Cem & Mars 6 multimode & $24 \times 100 \mathrm{ml}$ & $1800 \mathrm{~W}$ & Acid digestion, extraction, synthesis & {$[154]$} \\
\hline Milestone & Ultraclave multimode & $3.5 \mathrm{~L}$ & $1000 \mathrm{~W}$ & Digestion & {$[160]$} \\
\hline Milestone & Ethos Multimode & $12 \times 100 \mathrm{ml}$ & $1200 \mathrm{~W}$ & Digestion & {$[86]$} \\
\hline Sairem & Labotron hte multimode & $88 \mathrm{~L}$ & $6 \mathrm{~kW} 2.45 \mathrm{GHz}$ & Sintering & {$[161]$} \\
\hline Milestone & Mac - 75 multimode & $150 \mathrm{~L}$ & $4 \times 1500 W$ & Extraction & {$[162]$} \\
\hline Biotage & Initiator monomode & $60 \times 0.5-5 \mathrm{ml}$ & $1000 \mathrm{~W}$ & Synthesis, digestion & [79] \\
\hline Boke & MCR-3 Microwave Chemistry Reactor multimode & & $1350 \mathrm{~W}$ & Digestion & {$[163]$} \\
\hline
\end{tabular}

likewise, a homogeneous heat transfer to prevent hot spots formation which lead to the formation of degradation compounds.

The increasing use of MHP in the food industry, pharmaceutical and materials synthesis is demanding the development of industrial in-line process. Nevertheless for the development of this type of reactors it is necessary to deepen design of applicators (traveling wave, multimode, and monomode cavities), which enable highpower densities and faster heating rates. The development of electromagnetic models for the applicators would increase our understanding of MHP and enable an easier design to optimized microwave devices.

This technology has been applied to improve biological reactions such as enzymatic saccharification; however its use has been controversial because the non-thermal effect of microwaves in these reactions has not been specified completely. This fact would allow developing operational strategies to achieve higher fermentable sugars yields and the use of lower enzyme loading.

Moreover, the use of microwave heating processing to decrease the recalcitrance of the LCM is a technology that is just beginning to be developed and can be regarded as a technique that is not well established due to the few types of biomass which it has studied. Also is necessary to extend the knowledge of the best conditions for pretreatment optimization.

Thus, it is recommendable to study dielectric properties of LCMs in order to select the more convenient materials to MHP or to facilitate the searching of best pretreatment's conditions.

\section{Conclusion}

MHP is based on electromagnetic radiation and it is generated through the friction from the rotational forces on the polar molecules present, this technology is selective and volumetric. Materials heating depend on their dielectric, electrical and magnetic properties as well as on composition and shape. Heat generation occurs limitedly thus increasing energy efficiency, reducing processing times, avoiding the generation of degradation products and avoiding superficial overheating This work showed an overview of the use of MHP applied in different kind of LCMs pretreatment. MHP as pretreatment is the result of analysis combination and techniques to deliver a sustainable, economic and versatile process. Therefore it can be recommended as a technological option in the production of $2 \mathrm{G}$ biofuels. However, there is a little knowledge of dielectric properties and non-thermal effect. Indeed, a detailed knowledge of microwave engineering is required to develop efficiently microwave-heating equipment to a pilot or industrial scale.

\section{Acknowledgements}

Financial support is gratefully acknowledged from the Energy Sustainability Fund 2014-05 (CONACYT-SENER), Mexican Centre for Innovation in Bioenergy (Cemie-Bio), Cluster of Bioalcohols (Ref. 249564). This study was supported by the Secretary of Public Education of Mexico PROMEP project/103.5/13/6595 - UACOAHPTC-292 and PROMEP project/DSA/103.5/14/10442 - UACOAHPTC-312. We gratefully acknowledge support for this research by the Mexican Science and Technology Council (CONACYT, Mexico) for the infrastructure project - INFR201601 (Ref. 269461) and CB2015-01 (Ref. 254808). The author A. Aguilar-Reynosa thanks to Mexican Science and Technology Council (CONACY, Mexico) for master fellowship support.

\section{References}

[1] Gonçalves FA, Ruiz HA, dos Santos ES, Teixeira JA, de Macedo GR. Bioethanol production by Saccharomyces cerevisiae, Pichia stipitis and Zymomonas mobilis from delignified coconut fibre mature and lignin extraction according to biorefinery concept. Renew Energy 2016:352-65. http://dx.doi.org/10.1016/j. renene.2016.03.045.

[2] Romaní A, Ruiz HA, Teixeira JA, Domingues L. Valorization of Eucalyptus wood by glycerol-organosolv pretreatment within the biorefinery concept: an integrated and intensified approach. Renew Energy 2016;95:1-9. http://dx. doi.org/10.1016/j.renene.2016.03.106.

[3] Ruiz HA, Martínez A, Vermerris W. Bioenergy potential, energy crops, and biofuel production in Mexico. Bioenergy Res 2016;9:981-4. http://dx.doi.org/ 10.1007/s12155-016-9802-7.

[4] Ruiz HA, Silva DP, Ruzene DS, Lima LF, Vicente AA, Teixeira JA. Bioethanol production from hydrothermal pretreated wheat straw by a flocculating Saccharomyces cerevisiae strain - Effect of process conditions. Fuel 2012;95:528-36. http://dx.doi.org/10.1016/j.fuel.2011.10.060.

[5] Ruiz HA, Vicente AA, Teixeira JA Kinetic modeling of enzymatic saccharification using wheat straw pretreated under autohydrolysis and organosolv process. Ind Crops Prod 2012;36:100-7. http://dx.doi.org/ 10.1016/i.indcrop. 2011.08.014.

[6] Gonçalves FA, Ruiz HA, dos Santos ES, Teixeira JA, de Macedo GR. Bioethanol production from coconuts and cactus pretreated by autohydrolysis. Ind Crops Prod 2015;77:1-12. http://dx.doi.org/10.1016/i.indcrop.2015.06.041.

[7] Ruiz HA, Ruzene DS, Silva DP, Quintas MAC, Vicente AA, Teixeira JA Evaluation of a hydrothermal process for pretreatment of wheat straweffect of particle size and process conditions. J Chem Technol Biotechnol 2011;86:88-94. http://dx.doi.org/10.1002/jctb.2518.

[8] Nieves DC, Ruiz HA, de Cárdenas LZ, Alvarez GM, Aguilar CN, Ilyna A, et al. Enzymatic hydrolysis of chemically pretreated mango stem bark residues at high solid loading. Ind Crops Prod 2016;83:500-8. http://dx.doi.org/10.1016/ j.indcrop.2015.12.079.

[9] Ofori-Boateng CLK. Sono-assisted organosolv $/ \mathrm{H}_{2} \mathrm{O}_{2}$ pretreatment of oil palm (Elaeis guineensis Jacq.) fronds for recovery of fermentable sugars: optimization and severity evaluation. Fuel 2014;115:170-8.

[10] Alvira P, Tomás-Pejó E, Ballesteros M, Negro MJ. Pretreatment technologies for an efficient bioethanol production process based on enzymatic hydrolysis: areview. Bioresour Technol 2010;101:4851-61. http://dx.doi.org/10.1016/i. biortech.2009.11.093.

[11] Chiaramonti D, Prussi M, Ferrero S, Oriani L, Ottonello P, Torre P, et al. Review of pretreatment processes for lignocellulosic ethanol production, and development of an innovative method. Biomass Bioenergy 2012;46:25-35. http://dx.doi.org/10.1016/i.biombioe.2012.04.020.

[12] Ruiz HA, Rodríguez-Jasso RM, Aguedo M, Kádar Z. Hydrothermal pretreatment of macroalgal biomass for biorefineries. In: Prokop A, Bajpai RK, Zappi ME, editors. Algal Biorefineries. Springer International Publishing Switzerland; 2015. p. 467-91.

[13] Wan C, Li Y. Fungal pretreatment of lignocellulosic biomass. Biotechnol Adv 2012;30:1447-57. http://dx.doi.org/10.1016/i.biotechadv.2012.03.003.

[14] Gonçalves FA, Ruiz HA, Nogueira CC, dos Santos ES, Teixeira JA, de Macedo GR. Comparison of delignified coconuts waste and cactus for fuel-ethanol production by the simultaneous and semi-simultaneous saccharification 
and fermentation strategies. Fuel 2014;131:66-76. http://dx.doi.org/ 10.1016/i.fuel.2014.04.021.

[15] Peter R, Seidl AKG. Pretreatment processes for lignocellulosic biomass conversion to biofuels and bioproducts. Curr Opin Green Sustain Chem 2016:2:48-53.

[16] Ravindran R, Jaiswal AK. A comprehensive review on pre-treatment strategy for lignocellulosic food industry waste: challenges and opportunities. Bioresour Technol 2016;199:92-102. http://dx.doi.org/10.1016/i. biortech.2015.07.106.

[17] Rodríguez-Jasso RM, Mussatto SI, Pastrana L, Aguilar CN, Teixeira JA. Microwave-assisted extraction of sulfated polysaccharides (fucoidan) from brown seaweed. Carbohydr Polym 2011;86:1137-44. http://dx.doi.org/ 10.1016/i.carbpol.2011.06.006.

[18] Decareau Robert V. Microwave processing and engineering. Wiley-VCH Verlag GmbH; 1986.

[19] Rodríguez-Jasso RM, Mussatto SI, Pastrana L, Aguilar CN, Teixeira JA. Chemical composition and antioxidant activity of sulphated polysaccharides extracted from Fucus vesiculosus using different hydrothermal processes. Chem Pap 2014;68:203-9. http://dx.doi.org/10.2478/s11696-013-0430-9.

[20] Miranda MJ, Sebastián JL, Sierra MJ. Microondas Técnicas Experimentales. Madrid, España: Pearson Educación, S A; 2002.

[21] Motasemi F, Afzal MT. A review on the microwave-assisted pyrolysis technique. Renew Sustain Energy Rev 2013;28:317-30. http://dx.doi.org/ 10.1016/i.rser.2013.08.008.

[22] Sun J, Wang W, Yue Q, Ma C, Zhang J, Zhao X, et al. Review on microwavemetal discharges and their applications in energy and industrial processes.

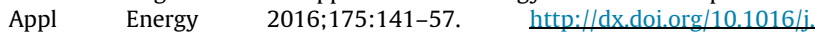
apenergy.2016.04.091.

[23] Sharma SK, Mulvaney SJ, Rizvi SSH. Food process engineering: theory and laboratory experiments. New York: John Wiley Sons Inc.; 1999.

[24] Tsubaki S, Azuma J. Application of Microwave Technology for Utilization of Recalcitrant Biomass. Adv Induction Microw Heat Miner Org Mater (Ed), ISBN 978-953-307-522-8, InTech, 2011. http://dx.doi.org/10.5772/14040.

[25] Salazar-González Claudia, San Martín-González Fernanda, López-Malo Aurelio. Recent studies related to microwave processing of fluid foods. Food Bioprocess Technol 2012;5:31-46. http://dx.doi.org/10.1007/s11947-0110639-y.

[26] La Hoz A. Microwave heating as, a tool for sustainable chemistry. ChemSusChem 2011. http://dx.doi.org/10.1002/cssc.201100003.

[27] Leonelli C, Mason T]. Microwave and ultrasonic processing: now a realistic option for industry. Chem Eng Process Process Intensif 2010;49:885-900. http://dx.doi.org/10.1016/j.cep.2010.05.006.

[28] Meda VV, Orsat VR. Microwave heating and the dielectric properties of foods. Microwave Process Foods. 2nd ed., 2017, p. 23-43.

[29] Palav T, Seetharaman K. Impact of microwave heating on the physicochemical properties of a starch-water model system. Carbohydr Polym 2007;67:596-604. http://dx.doi.org/10.1016/i.carbpol.2006.07.006.

[30] Salazar-González C, San Martín-González MF, López-Malo A, Sosa-Morales ME. Recent studies related to microwave processing of fluid foods. Food Bioprocess Technol 2011;5:31-46. http://dx.doi.org/10.1007/s11947-0110639-y.

[31] Datta Ashim K. RCA. Handbook of microwave technology for food application. New York: M. Dekker; 2001.

[32] Cuevas CL, Hernández BE. Use of microwaves in the pharmaceutical industry. Rev Mex Ciencias Farm 2011;42(Número):6-25.

[33] Sosa-Morales ME, Valerio-Junco L, López-Malo, García HS. Dielectric properties of foods: reported data in the 21st Century and their potential applications. LWT - Food. Sci Technol 2010;43:1169-79. http://dx.doi.org/ 10.1016/i.lwt.2010.03.017.

[34] Singh A, Bishnoi NR. Optimization of ethanol production from microwave alkali pretreated rice straw using statistical experimental designs by Saccharomyces cerevisiae. Ind Crops Prod 2012;37:334-41. http://dx.doi.org/ 10.1016/i.indcrop.2011.12.033.

[35] Yin C. Microwave-assisted pyrolysis of biomass for liquid biofuels production. Bioresour Technol 2012;120:273-84. http://dx.doi.org/10.1016/i. biortech.2012.06.016.

[36] Didier Stuerga. Microwave-material interactions and dielectric properties, key ingredients for mastery of chemical microwave processes. In: Loupy A, editor. Microwaves Org Synth. Weinheim, Germany: Wiley-VCH Verlag GmbH; 2006. http://dx.doi.org/10.1002/9783527619559 [ch1].

[37] Yousefi T, Mousavi S, Saghir MZ, Farahbakhsh B. An investigation on the microwave heating of flowing water: a numerical study. Int J Therm Sci 2013;71:118-27. http://dx.doi.org/10.1016/j.ijthermalsci.2013.04.006.

[38] Peyre F, Datta AK, Seyler C. Influence of the dielectric property on microwave oven heating patterns. J Microw Power Electromagn Energy 1997;32(1):3-15.

[39] Raju GG. Dielectrics in electric fields. New York: Marcel Dekker; 2003.

[40] Soto-Reyes N, Sosa-Morales RR. Modelación del calentamiento dieléctrico (microondas y radiofrecuencia) en sistemas alimenticios modelo. Temas Sel Ing Aliment 2012;6-2:19-31.

[41] Klinbun W, Rattanadecho P. Analysis of microwave induced natural convection in a single mode cavity (influence of sample volume, placement, and microwave power level). Appl Math Model 2012;36:813-28. http://dx. doi.org/10.1016/i.apm.2011.07.003.
[42] Chan CH, Yusoff R, Ngoh GC. Modeling and prediction of extraction profile for microwave-assisted extraction based on absorbed microwave energy. Food Chem 2013;140:147-53. http://dx.doi.org/10.1016/i.foodchem.2013.02.057.

[43] Cherbański R, Rudniak L. Modelling of microwave heating of water in a monomode applicator - Influence of operating conditions. Int J Therm Sci 2013;74:214-29. http://dx.doi.org/10.1016/j.ijthermalsci.2013.07.001.

[44] Chen J, Pitchai K, Birla S, Jones D, Negahban M, Subbiah J. Modeling heat and mass transport during microwave heating of frozen food rotating on a turntable. Food Bioprod Process 2016;99:116-27. http://dx.doi.org/10.1016/i. fbp.2016.04.009.

[45] Farag S, Sobhy A, Akyel C, Doucet J, Chaouki J. Temperature profile prediction within selected materials heated by microwaves at $2.45 \mathrm{GHz}$. Appl Therm Eng 2012;36:360-9. http://dx.doi.org/10.1016/i.applthermaleng.2011.10.049.

[46] Binner ER, Robinson JP, Silvester S, Kingman SW, Lester EH. Investigation into the mechanisms by which microwave heating enhances separation of waterin-oil emulsions. Fuel 2014;116:516-21. http://dx.doi.org/10.1016 i.fuel.2013.08.042.

[47] Lin Y-C, Chen S-C, Wu T-Y, Yang P-M, Jhang S-R, Lin J-F. Energy-saving and rapid transesterification of jatropha oil using a microwave heating system with ionic liquid catalyst. J Taiwan Inst Chem Eng 2014:1-7. http://dx.doi. org/10.1016/i.jtice.2014.11.014

[48] Xie Z, Yang J, Huang X, Huang Y. Microwave processing and properties of ceramics with different dielectric loss. J Eur Ceram Soc 1999;19:381-7. http://dx.doi.org/10.1016/S0955-2219(98)00203-9.

[49] Hoseinzadeh Hesas R, Wan Daud WMA, Sahu JN, Arami-Niya A. The effects of a microwave heating method on the production of activated carbon from agricultural waste: a review. J Anal Appl Pyrolysis 2013;100:1-11. http://dx. doi.org/10.1016/i.jaap.2012.12.019.

[50] Oghbaei M, Mirzaee O. Microwave versus conventional sintering: a review of fundamentals, advantages and applications. J Alloys Compd 2010;494:175-89. http://dx.doi.org/10.1016/i.jallcom.2010.01.068.

[51] Cheng SF, Nor LM, Chuah $\mathrm{CH}$. Microwave pretreatment: a clean and dry method for palm oil production. Ind Crops Prod 2011;34:967-71. http://dx. doi.org/10.1016/j.indcrop.2011.03.002.

[52] Karunanithy C, Muthukumarappan K, Gibbons WR. Sequential extrusionmicrowave pretreatment of switchgrass and big bluestem. Bioresour Technol 2014;153:393-8. http://dx.doi.org/10.1016/i.biortech.2013.12.032.

[53] Horikoshi S, Osawa A, Sakamoto S, Serpone N. Control of microwavegenerated hot spots. Part IV. Control of hot spots on a heterogeneous microwave-absorber catalyst surface by a hybrid internal/external heating method. Chem Eng Process Process Intensif 2013;69:52-6. http://dx.doi.org/ 10.1016/j.cep.2013.02.003.

[54] Campañone LA, Paola Ca, Mascheroni RH. Modeling and simulation of microwave heating of foods under different process schedules. Food Bioprocess Technol 2010;5:738-49. http://dx.doi.org/10.1007/s11947-010$\underline{0378-5 .}$

[55] Albella JM, Martín JMMD. Física de dieléctricos. Barcelona: Ed. MarcombO; 1984.

[56] Zhao X, Zhou Y, Zheng G, Liu D. Microwave pretreatment of substrates for cellulase production by solid-state fermentation. Appl Biochem Biotechnol 2010;160:1557-71. http://dx.doi.org/10.1007/s12010-009-8640-x.

[57] Motasemi F, Afzal MT, Salema AA, Mouris J, Hutcheon RM. Microwave dielectric characterization of switchgrass for bioenergy and biofuel. Fue 2014;124:151-7. http://dx.doi.org/10.1016/i.fuel.2014.01.085.

[58] Ayappa KG, Ayappa K. Modelling transport processes during microwave heating: a review. Rev Chem Eng 1997;13:1-69.

[59] Chandrasekaran S, Ramanathan S, Basak T. Microwave food processing - A review. Food Res Int 2013;52:243-61. http://dx.doi.org/10.1016 i.foodres.2013.02.033.

[60] Tsubaki S, Hiraoka M, Hadano S, Nishimura H, Kashimura K, Mitani T. Functional group dependent dielectric properties of sulfated hydrocolloids extracted from green macroalgal biomass. Carbohydr Polym 2014;107:192-7. http://dx.doi.org/10.1016/j.carbpol.2014.03.002.

[61] Hebbar HU, Rastogi NK. Microwave heating of fluids foods. In: Cullen PJ, Tiwary BK, Valdramidis VP, editors. Nov therm non-thermal technol fluid foods. London: Academic Press; 2012.

[62] Franco AP, Yamamoto LY, Tadini CC, Gut JaW. Dielectric properties of green coconut water relevant to microwave processing: effect of temperature and field frequency. J Food Eng 2015;155:69-78. http://dx.doi.org/10.1016/j. ifoodeng.2015.01.011.

[63] Zhang M, Tang J, Mujumdar AS, Wang S. Trends in microwave-related drying of fruits and vegetables. Trends Food Sci Technol 2006;17:524-34. http://dx. doi.org/10.1016/i.tifs.2006.04.011.

[64] Meredith R. Engineers' handbook of industrial microwave heating. London, United Kingdom: The instit, let; 1998. http://dx.doi.org/10.1049/PBPO025E.

[65] Lyng JG, Arimi JM, Scully M, Marra F. The influence of compositional changes in reconstituted potato flakes on thermal and dielectric properties and temperatures following microwave heating. J Food Eng 2014;124:133-42. http://dx.doi.org/10.1016/i.jfoodeng.2013.09.032.

[66] Ben Amor I, Arous M, Kallel A. Effect of maleic anhydride on dielectric properties of natural fiber composite. J Electrostat 2014;72:156-60. http://dx doi.org/10.1016/i.elstat.2013.12.006.

[67] Salema AA, Yeow YK, Ishaque K, Ani FN, Afzal MT, Hassan A. Dielectric properties and microwave heating of oil palm biomass and biochar. Ind Crops Prod 2013;50:366-74. http://dx.doi.org/10.1016/j.indcrop.2013.08.007. 
[68] Omar R, Idris, Yunus R, Khalid K, Aida Isma MI. Characterization of empty fruit bunch for microwave-assisted pyrolysis. Fuel 2011;90:1536-44. http://dx. doi.org/10.1016/i.fuel.2011.01.023.

[69] Torgovnikov GI. Dielectric properties of wood and wood based materials. Springer Series in Wood Science. Springer, London, Limited; 2011 [reprint].

[70] Bossou OV, Mosig JR, Zurcher J-F. Dielectric measurements of tropical wood. Measurement 2010;43:400-5. http://dx.doi.org/10.1016/i.measurement. 2009.12.008.

[71] El-Meligy MG, Mohamed SH, Mahani RM. Study mechanical, swelling and dielectric properties of prehydrolysed banana fiber - Waste polyurethane foam composites. Carbohydr Polym 2010;80:366-72. http://dx.doi.org 10.1016/i.carbpol.2009.11.034.

[72] Issa A, Al-Degs YS, Mashal K, Al Bakain RZ. Fast activation of natural biomasses by microwave heating. J Ind Eng Chem 2015;21:230-8. http://dx. doi.org/10.1016/i.jiec.2014.02.029.

[73] Shinoj S, Visvanathan R, Panigrahi S, Kochubabu M. Oil palm fiber (OPF) and its composites: a review. Ind Crops Prod 2011;33:7-22. http://dx.doi.org/ 10.1016/j.indcrop.2010.09.009.

[74] Budarin VL, Clark JH, Lanigan B, Shuttleworth P, Macquarrie DJ. Microwave assisted decomposition of cellulose: a new thermochemical route for biomass exploitation. Bioresour Technol 2010;101:3776-9. http://dx.doi.org/10.1016 i.biortech.2009.12.110.

[75] Tsubaki S, Oono K, Ueda T, Onda A, Yanagisawa K, Mitani T. Microwaveassisted hydrolysis of polysaccharides over polyoxometalate clusters. Bioresour Technol 2013;144:67-73. http://dx.doi.org/10.1016/j.biortech 2013.06.092.

[76] Xia A, Cheng J, Song W, Yu C, Zhou J, Cen K. Enhancing enzymatic saccharification of water hyacinth through microwave heating with dilute acid pretreatment for biomass energy utilization. Energy 2013;61:158-66. http://dx.doi.org/10.1016/i.energy.2013.09.019.

[77] Tsubaki S, Oono K, Onda A, Yanagisawa K, Azuma JI. Microwave-assisted hydrothermal hydrolysis of cellobiose and effects of additions of halide salts Bioresour Technol 2012;123:703-6. http://dx.doi.org/10.1016/i. biortech.2012.07.086.

[78] Tsubaki S, Ozaki JA. Microwave-assisted autohydrolysis of Prunus mume stone for extraction of polysaccharides and phenolic compounds. J Food Sci 2010;75:C152-9.

[79] Verma P, Watanabe T, Honda Y, Watanabe T. Microwave-assisted pretreatment of woody biomass with ammonium molybdate activated by $\mathrm{H}_{2} \mathrm{O}_{2}$. Bioresour Technol 2011;102:3941-5. http://dx.doi.org/10.1016/i. biortech.2010.11.058

[80] Aguedo M, Ruiz HA, Richel A. Non-alkaline solubilization of arabinoxylans from destarched wheatbran using hydrothermal microwave processing and comparison with the hydrolysis by an endoxylanase. Chem Eng Process Process Intensif 2015;96:72-82. http://dx.doi.org/10.1016/ j.cep.2015.07.020.

[81] Perez-Pimienta JA, Flores-Gómez CA, Ruiz HA, Sathitsuksanoh N, Balan V, et al. Evaluation of agave bagasse recalcitrance using AFEXTM autohydrolysis, and ionic liquid pretreatments. Bioresour Technol 2016;211:216-23. http://dx.doi.org/10.1016/i.biortech.2016.03.103.

[82] Ruiz HA, Rodríguez-Jasso RM, Fernandes BD, Vicente AA, Teixeira JA Hydrothermal processing, as an alternative for upgrading agriculture residues and marine biomass according to the biorefinery concept: a review. Renew Sustain Energy Rev 2013;21:35-51. http://dx.doi.org 10.1016/i.rser.2012.11.069.

[83] Anwar J, Shafique U, Waheed-uz-Zaman Rehman R, Salman M, Dar A, et al Microwave chemistry: effect of ions on dielectric heating in microwave ovens. Arab J Chem 2015;8:100-4. http://dx.doi.org/10.1016/i. arabjc.2011.01.014

[84] Takahashi K, Takenaka H. Electrical conductivity of cellulose. Polym 1983;15:625-9.

[85] Shi J, Pu Y, Yang B, Ragauskas A, Wyman CE. Comparison of microwaves to fluidized sand baths for heating tubular reactors for hydrothermal and dilute acid batch pretreatment of corn stover. Bioresour Technol 2011;102:5952-61. http://dx.doi.org/10.1016/i.biortech.2011.03.027.

[86] Gabhane J, Prince William SPM, Vaidya AN, Mahapatra K, Chakrabarti T. Influence of heating source on the efficacy of lignocellulosic pretreatment - A cellulosic ethanol perspective. Biomass Bioenergy 2011;35:96-102. http://dx. doi.org/10.1016/j.biombioe.2010.08.026.

[87] Hu Z, Wen Z. Enhancing enzymatic digestibility of switchgrass by microwaveassisted alkali pretreatment. Biochem Eng J 2008;38:369-78. http://dx.doi. org/10.1016/j.bej.2007.08.001.

[88] Pitchai K, Birla S, Subbiah J, Jones DD, Thippareddi H. Coupled electromagnetic and heat transfer model for microwave heating in domestic ovens. J Food Eng 2012;112:100-11.

[89] Wang H, Maxim ML, Gurau G, Rogers RD. Microwave-assisted dissolution and delignification of wood in 1-ethyl-3-methylimidazolium acetate. Bioresour Technol 2013;136:739-42. http://dx.doi.org/10.1016/j. biortech.2013.03.064.

[90] Ooshima H, Aso K, Harano Y, Yamamoto T. Microwave treatment of cellulosic materials for their enzymatic hydrolysis. Biotechnol Lett 1984;6:289-94. http://dx.doi.org/10.1007/BF00129056.

[91] Azuma J, Tanaka FKT. Enhancement of enzymatic susceptibility of lignocellulosic wastes by microwave irradiation. J Ferment Technol 1984;62:377-84.
[92] Gabhane J, Prince William SPM, Gadhe A, Rath R, Vaidya AN, Wate S. Pretreatment of banana agricultural waste for bio-ethanol production: individual and interactive effects of acid and alkali pretreatments with autoclaving, microwave heating and ultrasonication. Waste Manage 2014;34:498-503. http://dx.doi.org/10.1016/j.wasman.2013.10.013.

[93] Zhu Z, Rezende CA, Simister R, McQueen-Mason SJ, Macquarrie DJ, Polikarpov I, et al. Efficient sugar production from sugarcane bagasse by microwave assisted acid and alkali pretreatment. Biomass Bioenergy 2016;93:269-78. http://dx.doi.org/10.1016/i.biombioe.2016.06.017.

[94] Akhtar N, Goyal D, Goyal A. Characterization of microwave-alkali-acid pretreated rice straw for optimization of ethanol production via simultaneous saccharification and fermentation (SSF). Energy Convers Manage; 2016. http://dx.doi.org/10.1016/i.enconman.2016.06.081 [In press].

[95] Singh R, Tiwari S, Srivastava M, Shukla A. Microwave assisted alkali pretreatment of rice straw for enhancing enzymatic digestibility. J Energy 2014;2014:1-7. http://dx.doi.org/10.1155/2014/483813.

[96] Lai LW, Idris A. Comparison of steam-alkali-chemical and microwave-alkali pretreatment for enhancing the enzymatic saccharification of oil palm trunk. Renew Energy 2016;99:738-46. $\quad$ http://dx.doi.org/10.1016/i. renene.2016.07.059

[97] Zhu S, Wu Y, Yu Z, Liao J, Zhang Y. Pretreatment by microwave/alkali of rice straw and its enzymic hydrolysis. Process Biochem 2005;40:3082-6. http:/ dx.doi.org/10.1016/j.procbio.2005.03.016.

[98] Zhu S, Wu Y, Yu Z, Chen Q, Wu G, Yu F, et al. Microwave-assisted alkali pretreatment of wheat straw and its enzymatic hydrolysis. Biosyst Eng 2006;94:437-42. http://dx.doi.org/10.1016/i.biosystemseng.2006.04.002.

[99] Hu Z, Wang Y, Wen Z. Alkali (NaOH) pretreatment of switchgrass by radio frequency-based dielectric heating. Appl Biochem Biotechnol 2008;148:71-81. http://dx.doi.org/10.1007/s12010-007-8083-1.

[100] Janker-Obermeier I, Sieber V, Faulstich M, Schieder D. Solubilization of hemicellulose and lignin from wheat straw through microwave-assisted alkali treatment. Ind Crops Prod 2012;39:198-203. http://dx.doi.org/ 10.1016/j.indcrop.2012.02.022.

[101] Vani S, Binod P, Kuttiraja M, Sindhu R, Sandhya SV, Preeti VE, et al. Energy requirement for alkali assisted microwave and high pressure reactor pretreatments of cotton plant residue and its hydrolysis for fermentable sugar production for biofuel application. Bioresour Technol 2012;112:300-7. http://dx.doi.org/10.1016/i.biortech.2012.02.076

[102] Chen W-H, Tu Y-J, Sheen H-K. Disruption of sugarcane bagasse lignocellulosic structure by means of dilute sulfuric acid pretreatment with microwaveassisted heating. Appl Energy 2011;88:2726-34. http://dx.doi.org/10.1016/i. apenergy.2011.02.027.

[103] Chen W-H, Ye S-C, Sheen H-K. Hydrolysis characteristics of sugarcane bagasse pretreated by dilute acid solution in a microwave irradiation environment. Appl Energy 2012;93:237-44. http://dx.doi.org/10.1016/i. apenergy.2011.12.014.

[104] Gong G, Liu D, Huang Y. Microwave-assisted organic acid pretreatment for enzymatic hydrolysis of rice straw. Biosyst Eng 2010;107:67-73. http://dx. doi.org/10.1016/i.biosystemseng.2010.05.012.

[105] Liu J, Takada R, Karita S, Watanabe T, Honda Y, Watanabe T. Microwaveassisted pretreatment of recalcitrant softwood in aqueous glycerol. Bioresour

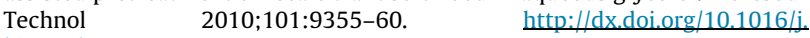
biortech.2010.07.023.

[106] Ma H, Liu W-W, Chen X, Wu Y-J, Yu Z-L. Enhanced enzymatic saccharification of rice straw by microwave pretreatment. Bioresour Technol 2009;100:1279-84. http://dx.doi.org/10.1016/i.biortech.2008.08.045.

[107] Choudhary R, Umagiliyage AL, Liang Y, Siddaramu T, Haddock J, Markevicius G. Microwave pretreatment for enzymatic saccharification of sweet sorghum bagasse. Biomass Bioenergy 2012;39:218-26. http://dx.doi.org/10.1016/i. biombioe.2012.01.006.

[108] Pang F, Xue S, Yu S, Zhang C, Li B, Kang Y. Effects of microwave power and microwave irradiation time on pretreatment efficiency and characteristics of corn stover using combination of steam explosion and microwave irradiation (SE-MI) pretreatment. Bioresour Technol 2012;118:111-9. http://dx.doi.org/ 10.1016/i.biortech.2012.05.041.

[109] Pang F, Xue S, Yu S, Zhang C, Li B, Kang Y. Effects of combination of steam explosion and microwave irradiation (SE-MI) pretreatment on enzymatic hydrolysis, sugar yields and structural properties of corn stover. Ind Crops Prod 2013;42:402-8. http://dx.doi.org/10.1016/j.indcrop.2012. $\underline{06.016}$.

[110] Kristiani A, Effendi N, Aristiawan Y, Aulia F, Sudiyani Y. Effect of combining chemical and irradiation pretreatment process to characteristic of oil palm's empty fruit bunches as raw material for second generation bioethanol. Energy Proc 2015;68:195-204. http://dx.doi.org/10.1016/j.egypro.2015. $\underline{03.248 .}$.

[111] Feng Y, Li G, Li X, Zhu N, Xiao B, Li J, et al. Enhancement of biomass conversion in catalytic fast pyrolysis by microwave-assisted formic acid pretreatment. Bioresour Technol 2016;214:520-7. http://dx.doi.org/10.1016/j.biortech. 2016.04.137.

[112] Kaur K, Phutela UG. Enhancement of paddy straw digestibility and biogas production by sodium hydroxide-microwave pretreatment. Renew Energy 2016;92:178-84. http://dx.doi.org/10.1016/i.renene.2016.01.083.

[113] Li Q, Guo C, Liu CZ. Dynamic microwave-assisted alkali pretreatment of cornstalk to enhance hydrogen production via co-culture fermentation of Clostridium thermocellum and Clostridium thermosaccharolyticum. Biomass 
Bioenergy 2014;64:220-9. $\quad$ http://dx.doi.org/10.1016/i.biombioe.2014. 03.053.

[114] Hamzah F, Idris A, Rashid R, Ming SJ. Lactic acid production from microwavealkali pretreated empty fruit bunches fibre using Rhizopus oryzae pellet. J Appl Sci 2009;9:3086-91.

[115] Wang LL, Han YMZ GT. Comparative study of composition, structure and properties of Apocynum venetum fibers under different pretreatments. Carbohydr Polym 2007;69:391-7.

[116] Palmarola-Adrados B, Galbe M, Zacchi G. Pretreatment of barley husk for bioethanol production. J Chem Technol Biotechnol 2005;80:85-91. http://dx. doi.org/10.1002/jctb.1161.

[117] Lu X, Xi B, Zhang Y, Angelidaki I. Microwave pretreatment of rape straw for bioethanol production: focus on energy efficiency. Bioresour Technol 2011;102:7937-40. http://dx.doi.org/10.1016/j.biortech.2011.06.065.

[118] Sasaki C, Takada R, Watanabe T, Honda Y, Karita S, Nakamura Y, et al. Surface carbohydrate analysis and bioethanol production of sugarcane bagasse pretreated with the white rot fungus, Ceriporiopsis subvermispora and microwave hydrothermolysis. Bioresour Technol 2011;102:9942-6. http:// dx.doi.org/10.1016/i.biortech.2011.07.027.

[119] Chen C, Boldor D, Aita G, Walker M. Ethanol production from sorghum by a microwave-assisted dilute ammonia pretreatment. Bioresour Technol 2012;110:190-7. http://dx.doi.org/10.1016/i.biortech.2012.01.021.

[120] Singh A, Bajar S, Bishnoi NR. Enzymatic hydrolysis of microwave alkali pretreated rice husk for ethanol production by Saccharomyces cerevisiae, Scheffersomyces stipitis and their co-culture. Fuel 2014;116:699-702. http:/ dx.doi.org/10.1016/i.fuel.2013.08.072.

[121] Marx S, Ndaba B, Chiyanzu I, Schabort C. Fuel ethanol production from sweet sorghum bagasse using microwave irradiation. Biomass Bioenergy 2013:1-6. http://dx.doi.org/10.1016/i.biombioe.2013.11.019.

[122] Rodrigues THS, Rocha MVP, De MacEdo GR, Goncalves LRB. Ethanol production from cashew apple bagasse: Improvement of enzymatic hydrolysis by microwave-assisted alkali pretreatment. Appl Biochem Biotechnol 2011;164:929-43. http://dx.doi.org/10.1007/s12010-011-9185-3.

[123] Kannan TS, Ahmed ASAF. Energy efficient microwave irradiation of sago bark waste (SBW) for bioethanol production. Adv Mater Res 2013;701:249-53.

[124] Gude VG. Synergism of microwaves and ultrasound for advanced biorefineries. Resource Technol 2015;1:116-25. http://dx.doi.org/10.1016/i. reffit.2015.10.001.

[125] Bussemaker MJ, Mu X, Zhang D. Ultrasonic pretreatment of wheat straw in oxidative and nonoxidative conditions aided with microwave heating. Ind Eng Chem Res 2013;52:12514-22. http://dx.doi.org/10.1021/ie401181f.

[126] Mai NL, Ha SH, Koo YM. Efficient pretreatment of lignocellulose in ionic liquids/co-solvent for enzymatic hydrolysis enhancement into fermentable sugars. Process Biochem 2014:49:1144-51.

[127] Darji D, Alias Y, Som FMRN. Microwave heating and hydrolysis of rubber wood biomass in ionic liquids. J Chem Technol Biotechnol 2015;90:2050-6.

[128] Nomanbhay SM. Microwave-assisted alkaline pretreatment and microwave assisted enzymatic saccharification of oil palm empty fruit bunch fiber for enhanced fermentable sugar yield. J Sustain Bioenergy Syst 2013;03:7-17. http://dx.doi.org/10.4236/isbs.2013.31002.

[129] Yadav GD, Lathi P. Microwave assisted enzyme catalysis for synthesis of $n-$ butyl dipheyl methyl mercapto acetate in non-aqueous media. Clean Technol Environ Policy 2007;9:281-7.

[130] Conesa C, Seguí L, Laguarda-Miró N, Fito P. Microwaves as a pretreatment for enhancing enzymatic hydrolysis of pineapple industrial waste for bioethanol production. Food Bioprod Process 2016. http://dx.doi.org/10.1016/i. fbp.2016.07.001.

[131] Kumar C, Joardder M, Karim A, Millar GJ, Amin Z. Temperature redistribution modelling during intermittent microwave connective heating. Proc Eng 2014;90:544-9.

[132] Roy Ipsita, Gupta MN. Applications of microwaves in biological sciences. Curr Sci 2003;85.

[133] Jiliang Lü PZ. Optimization of microwave-assisted $\mathrm{FeCl}_{3}$ pretreatment conditions of rice straw and utilization of Trichoderma viride and Bacillus pumilus for production of reducing sugars. Bioresour Technol 2011;102:6966-71. http://dx.doi.org/10.1016/j.biortech.2011.04.044.

[134] Keshwani DR, Cheng JJ. Microwave-based alkali pretreatment of switchgrass and coastal bermudagrass for bioethanol production. Biotechnol Prog 2010;26:644-52. http://dx.doi.org/10.1002/btpr.371.

[135] Diaz AB, Moretti MMDS, Bezerra-Bussoli C, Carreira Nunes CDC, Blandino A, da Silva R, et al. Evaluation of microwave-assisted pretreatment of lignocellulosic biomass immersed in alkaline glycerol for fermentable sugars production. Bioresour Technol 2015;185:316-23. http://dx.doi.org/ 10.1016/j.biortech.2015.02.112.

[136] Ninomiya K, Yamauchi T, Ogino C, Shimizu N, Takahashi K. Microwave pretreatment of lignocellulosic material in cholinium ionic liquid for efficient enzymatic saccharification. Biochem Eng J 2014;90:90-5. http://dx.doi.org/ 10.1016/j.bej.2014.05.013 [Short communication].

[137] Jin S, Zhang G, Zhang P, Li F, Wang S, Fan S, et al. Microwave assisted alkaline pretreatment to enhance enzymatic saccharification of catalpa sawdust. Bioresour Technol 2016;221:26-30. http://dx.doi.org/10.1016/i. biortech.2016.09.033.

[138] Moretti MMDS, Bocchini-Martins DA, Nunes CDCC, Villena MA, Perrone OM, Silva $R$, et al. Pretreatment of sugarcane bagasse with microwaves irradiation and its effects on the structure and on enzymatic hydrolysis. Appl Energy 2014;122:189-95. http://dx.doi.org/10.1016/j.apenergy.2014.02.020.
[139] Rorke DCS, Suinyuy TN, Gueguim Kana EB. Microwave-assisted chemical pre-treatment of waste sorghum leaves: process optimization and development of an intelligent model for determination of volatile compound fractions. Bioresour Technol 2016. http://dx.doi.org/10.1016/i biortech.2016.10.048.

[140] Zhang Z, Zhao ZK. Microwave-assisted conversion of lignocellulosic biomass into furans in ionic liquid. Bioresour Technol 2010;101:1111-4. http://dx.doi. org/10.1016/j.biortech.2009.09.010.

[141] Lacerda VS, López-Sotelo JB, Correa-Guimarães A, Hernández-Navarro S, et al A kinetic study on microwave-assisted conversion of cellulose and lignocellulosic waste into hydroxymethylfurfural/furfural. Bioresour Technol 2015;180:88-96. http://dx.doi.org/10.1016/j.biortech.2014.12.089.

[142] Wang T-H, Lu S. Production of xylooligosaccharide from wheat bran by microwave assisted enzymatic hydrolysis. Food Chem 2013;138:1531-5. http://dx.doi.org/10.1016/j.foodchem.2012.09.124.

[143] Prakash Maran J, Sivakumar V, Thirugnanasambandham K, Sridhar R. Microwave assisted extraction of pectin from waste Citrullus lanatus fruit rinds. Carbohydr Polym 2014;101:786-91. http://dx.doi.org/10.1016/ i.carbpol.2013.09.062.

[144] Bu Q, Lei H, Ren S, Wang L, Holladay J, Zhang Q, et al. Phenol and phenolics from lignocellulosic biomass by catalytic microwave pyrolysis. Bioresour Technol 2011;102:7004-7. http://dx.doi.org/10.1016/i.biortech.2011.04.025.

[145] Zhou S, Liu L, Wang B, Xu F, Sun R. Microwave-enhanced extraction of lignin from birch in formic acid: structural characterization and antioxidant activity study. Process Biochem 2012;47:1799-806. http://dx.doi.org/10.1016/i procbio.2012.06.006.

[146] Jackowiak D, Frigon JC, Ribeiro T, Pauss, Guiot S. Enhancing solubilisation and methane production kinetic of switchgrass by microwave pretreatment. Bioresour Technol 2011;102:3535-40. http://dx.doi.org/10.1016/i biortech.2010.11.069.

[147] Sequeiros A, Serrano L, Briones R, Labidi J. Lignin liquefaction under microwave heating. J Appl Polym Sci 2013;130:3292-8. http://dx.doi.org/ 10.1002/app.39577.

[148] Cheng J, Zhou JH, Li YC, Liu JZCK. Improvement of coal water slurry property through coal physicochemical modifications by microwave irradiation and thermal heat. Energy Fuels 2008;22:2422-8.

[149] Limayem A, Ricke SC. Lignocellulosic biomass for bioethanol production Current perspectives, potential issues and future prospects. Prog Energy Combust Sci 2012;38:449-67. http://dx.doi.org/10.1016/i.pecs.2012.03.002.

150] Erdei B, Hancz D, Galbe M, Zacchi G. SSF of steam-pretreated wheat straw with the addition of saccharified or fermented wheat meal in integrated bioethanol production. Biotechnol Biofuels 2013;6:169. http://dx.doi.org/ 10.1186/1754-6834-6-169.

[151] Romaní A, Ruiz HA, Pereira FB, Teixeira JA, Domingues L. Integrated approach for effective bioethanol production using whole slurry from autohydrolyzed Eucalyptus globulus wood at high-solid loadings. Fuel 2014;135:482-91. http://dx.doi.org/10.1016/i.fuel.2014.06.061.

[152] Popescu S, Misawa T, Ohtsu Y, Fujita H, Sanematsu S. New microwave reactor for paper-based waste neutralization. Resour Conserv Recycl 2008;52:671-7. http://dx.doi.org/10.1016/i.resconrec.2007.09.003.

[153] Schön U, Messinger J, Eichner S, Kirschning A. Comparison of monomode and multimode microwave equipment in Suzuki-Miyaura reactions-en route to high throughput parallel synthesis under microwave conditions. Tetrahedron Lett 2008;49:3204-7. http://dx.doi.org/10.1016/i.tetlet.2008.03.094.

[154] Komorowska-Durka M, Loo MBT, Sturm GSJ, Radoiu M, Oudshoorn M, Van Gerven $\mathrm{T}$, et al. Novel microwave reactor equipment using internal transmission line (INTLI) for efficient liquid phase chemistries: a study-case of polyester preparation. Chem Eng Process Process Intensif 2013;69:83-9. http://dx.doi.org/10.1016/i.cep.2013.03.003.

[155] Leadbeater NE, Schmink JR. Use of a scientific microwave apparatus for rapid optimization of reaction conditions in a monomode function and then substrate screening in a multimode function. Tetrahedron 2007;63:6764-73. http://dx.doi.org/10.1016/j.tet.2007.04.074.

[156] Mehdizadeh M. Microwave Multimode Cavities for Material Heating. Microwave/RF Appl Probes Mater Heating, Sensing, Plasma Gener A Des Guid, William Andrew; 2010, p. 151-82 [chapter 5].

[157] Mehdizadeh. M. Single-mode microwave cavities for material processing and sensing. Microwave/RF Appl Probes Mater Heating, Sensing, Plasma Gener A Des Guid, William Andrew; 2010, p. 109-50 [chapter 4].

[158] Antes FG, Duarte FA, Mesko MF, Nunes MaG, Pereira Va, Müller EI, et al Determination of toxic elements in coal by ICP-MS after digestion using microwave-induced combustion. Talanta 2010;83:364-9. http://dx.doi.org/ 10.1016/j.talanta.2010.09.030.

[159] Butt T, Tosheva L. Microporous and mesoporous materials synthesis of colloidal silicalite-1 at high temperatures. Microporous Mesoporous Mater 2014;187:71-6. http://dx.doi.org/10.1016/j.micromeso.2013.12.021.

[160] Li X, Dai S, Zhang W, Li T, Zheng X, Chen W. Determination of As and Se in coal and coal combustion products using closed vessel microwave digestion and collision/reaction cell technology (CCT) of inductively coupled plasma mass spectrometry (ICP-MS). Int J Coal Geol 2014;124:1-4. http://dx.doi.org 10.1016/i.coal.2014.01.002

[161] Thuault A, Savary E, Bazin J, Marinel S. Microwave sintering of large size pieces with complex shape. J Mater Process Technol 2014;214:470-6. http:/ dx.doi.org/10.1016/i.jmatprotec.2013.09.030.

[162] Filly A, Fernandez X, Minuti M, Visinoni F, Cravotto G, Chemat F. Solvent-free microwave extraction of essential oil from aromatic herbs: from laboratory to 
pilot and industrial scale. Food Chem 2014;150:193-8. http://dx.doi.org/ 10.1016/j.foodchem.2013.10.139.

[163] Li H, Xu J. Optimization of microwave-assisted calcium chloride pretreatment of corn stover. Bioresour Technol 2013;127:112-8. http://dx.doi.org 10.1016/i.biortech.2012.09.114.

[164] Peng H, Luo H, Jin S, Li H, Xu J. Improved bioethanol production from corn stover by alkali pretreatment with a novel pilot-scale continuous microwave irradiation reactor. Biotechnol Bioprocess Eng 2014;19:493-502. http://dx. doi.org/10.1007/s12257-014-0014-8.

[165] Périno Sandrine, Pierson Jean T, Ruiz Karine, Cravotto G, Chemat F. Laboratory to pilot scale: microwave extraction for polyphenols lettuce. Food Chem 2016;204:108-14. 